\title{
1 SARS-CoV-2 specific T cell responses are lower in children and increase with age
}

\section{2 and time after infection}

3 Carolyn A Cohen ${ }^{1}$, Athena PY Li ${ }^{1}$, Asmaa Hachim ${ }^{1}$, David SC Hui ${ }^{2}$, Mike YW Kwan ${ }^{3}$, Owen

4 TY Tsang ${ }^{4}$, Susan S Chiu ${ }^{5}$, Wai Hung Chan ${ }^{6}$, Yat Sun Yau ${ }^{6}$, Niloufar Kavian ${ }^{1}$, Fionn NL

$5 \mathrm{Ma}^{1}$, Eric HY Lau ${ }^{7}$, Samuel MS Cheng ${ }^{8}$, Leo LM Poon ${ }^{1,8}$, JS Malik Peiris ${ }^{1,8}$ and Sophie A

6 Valkenburg $^{1 *}$

\section{$8 \quad$ Affiliation}

9 'HKU-Pasteur Research Pole, School of Public Health, Li Ka Shing Faculty of Medicine, The University of 10 Hong Kong, Hong Kong SAR, China.

$11{ }^{2}$ Department of Medicine and Therapeutics, Prince of Wales Hospital, Chinese University of Hong Kong, 12 Hong Kong SAR, China.

$13{ }^{3}$ Department of Paediatric and Adolescent Medicine, Hong Kong Hospital Authority Infectious Disease

14 Center, Princess Margaret Hospital, Special Administrative Region of Hong Kong, China.

$15{ }^{4}$ Infectious Diseases Centre, Princess Margaret Hospital, Hospital Authority of Hong Kong, Special

16 Administrative Region of Hong Kong, China.

$17{ }^{5}$ Department of Paediatric and Adolescent Medicine, The University of Hong Kong and Queen Mary Hospital,

18 Hospital Authority of Hong Kong, Special Administrative Region of Hong Kong, China.

$19{ }^{6}$ Department of Paediatrics, Queen Elizabeth Hospital, Hospital Authority of Hong Kong, Special

20 Administrative Region of Hong Kong, China.

$21{ }^{7}$ WHO Collaborating Centre for Infectious Disease Epidemiology and Control, School of Public Health, Li Ka 22 Shing Faculty of Medicine, The University of Hong Kong, Hong Kong SAR, China.

$23{ }^{8}$ Division of Public Health Laboratory Sciences, School of Public Health, Li Ka Shing Faculty of Medicine, The 24 University of Hong Kong, Hong Kong SAR, China.

$26{ }^{*}$ Corresponding author:

27 Dr Sophie A Valkenburg

28 HKU Pasteur Research Pole, School of Public Health, The University of Hong Kong

29 Tel: +852 2831 5501, sophiev@hku.hk

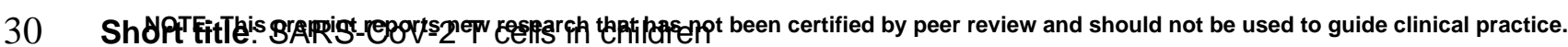

31 Keywords: T cells, SARS-CoV-2, COVID19, asymptomatic, paediatric, common cold coronavirus 


\section{Abstract}

33 SARS-CoV-2 infection of children leads to a mild illness and the immunological differences

34 with adults remains unclear. We quantified the SARS-CoV-2 specific T cell responses in 35 adults and children ( $<13$ years of age) with RT-PCR confirmed asymptomatic and 36 symptomatic infection for long-term memory, phenotype and polyfunctional cytokines.

37 Acute and memory $\mathrm{CD}^{+} \mathrm{T}$ cell responses to structural SARS-CoV-2 proteins significantly 38 increased with age, whilst $\mathrm{CD}^{+} \mathrm{T}$ cell responses increased with time post infection.

39 Infected children had significantly lower $\mathrm{CD}^{+}$and $\mathrm{CD} 8^{+} \mathrm{T}$ cell responses to SARS-CoV-2

40 structural and ORF1ab proteins compared to infected adults. SARS-CoV-2-specific CD8 ${ }^{+} \mathrm{T}$

41 cell responses were comparable in magnitude to uninfected negative adult controls. In

42 infected adults $\mathrm{CD}^{+} \mathrm{T}$ cell specificity was skewed towards structural peptides, whilst

43 children had increased contribution of ORF1ab responses. This may reflect differing $T$ cell

44 compartmentalisation for antigen processing during antigen exposure or lower recruitment

45 of memory populations. T cell polyfunctional cytokine production was comparable between

46 children and adults, but children had a lower proportion of SARS-CoV-2 CD4 ${ }^{+} \mathrm{T}$ cell

47 effector memory. Compared to adults, children had significantly lower levels of antibodies

48 to $\beta$-coronaviruses, indicating differing baseline immunity. Total $\mathrm{T}$ follicular helper

49 responses was increased in children during acute infection indicating rapid co-ordination of

50 the $\mathrm{T}$ and $\mathrm{B}$ cell responses. However total monocyte responses were reduced in children

51 which may be reflective of differing levels of inflammation between children and adults.

52 Therefore, reduced prior $\beta$-coronavirus immunity and reduced activation and recruitment of

53 de novo responses in children may drive milder COVID-19 pathogenesis. 


\section{Introduction}

55 A lack of pre-existing SARS-CoV-2-specifc protective antibodies has led to the rapid global

56 spread of the novel coronavirus, however the large majority of infections are reportedly

57 asymptomatic or mild (Ing et al., 2020). Previous COVID-19 infection may protect from

58 reinfection (Addetia et al., 2020, Lumley et al., 2020) and neutralizing antibodies are likely

59 to play an important protective role (Chandrashekar et al., 2020). However, the emergence

60 of variant strains (e.g. 501Y.V2) suggests the possibility of escape from previous

61 neutralizing antibody (Greaney et al., 2020, Cele et al., 2021). Antibody based treatment of

62 established infection has had minimal beneficial effect on clinical outcome in COVID-19

63 patients (Weinreich et al., 2020) and may lead to emergence of escape mutant variants

64 (Kemp et al., 2020). Dysregulated innate immune responses, such as auto-interferon

65 antibodies or delayed responsiveness has been reported in some severe COVID-19 cases

66 but cannot account for the majority of severe infections (Blanco-Melo et al., 2020, Chen et

67 al., 2020, Wang et al., 2020). Importantly, a coordinated cellular immune response has

68 been key to clinical resolution of SARS-CoV-2 infection (Rydyznski Moderbacher et al.,

69 2020).

Pre-existing cross-reactive antibodies elicited by exposure to endemic human

71 common cold coronaviruses such as the related $\beta$-coronavirus OC43 and HKU-1, do not

72 prevent infection with SARS-CoV-2 (Anderson et al., 2020, Edridge et al., 2020).

73 Furthermore, pre-existing cross-reactive $\mathrm{T}$ cell immunity generated by common cold

74 coronaviruses has also been detected in the majority of people (Tan et al., 2021), with

75 epitope conservation mostly reported in the ORF1ab non-structural proteins (Grifoni et al.,

76 2020), but SARS-CoV-2 cross-reactive T cell responses have also been detected despite

77 lower (<67\%) epitope homology (Mateus et al., 2020). Upon infection, T cell responses

78 shift towards Spike and Nucleocapsid structural proteins (Le Bert et al., 2020, Mateus et

79 al., 2020). However, cross-reactive $\mathrm{CD}^{+} \mathrm{T}$ cell responses have been reported as similar

80 (Mateus et al., 2020) or lower avidity and may be associated with worsening clinical 
outcomes (Bacher et al., 2020). In animal models of re-infection, Spike-specific CD8 ${ }^{+} \mathrm{T}$ cell responses can compensate for inadequate antibody responses and may provide an immune correlate of protection (McMahan et al., 2020). The magnitude of ORF1ab specific SARS-CoV-2 T cell responses during infection of adults does not differ with symptom severity but does associate with reduced duration of illness (Le Bert et al., 2020). Therefore, determining the balance and specificity of SARS-CoV-2-specific $T$ cell responses for structural, accessory and non-structural proteins may inform the COVID-19 response and pathogenesis.

Following mild COVID-19 infection SARS-CoV-2 specific memory B cells are

90 established for at least 6 months with long-term stability that may be recruited upon 91 reinfection (Rodda et al., 2021). T cells following SARS-CoV infection in 2003 have reassuringly been detected 17 years after infection (Le Bert et al., 2020). Robust adaptive antibody and $\mathrm{T}$ cell responses have been reported in symptomatic and asymptomatic SARS-CoV-2 infected adults (Long et al., 2020, Sekine et al., 2020). Although serum antibody response to the common cold coronaviruses maybe long lasting, reinfection is common one or more years after infection (Edridge et al., 2020). The severity of COVID-19 may be reduced by rapid and early recruitment of established immune responses (Thevarajan et al., 2020, Chan et al., 2020, Tosif et al., 2020). The early and rapid recruitment of $T$ follicular helper (Tfh) cells (Juno et al., 2020) drives early antibody development (Thevarajan et al., 2020) by germinal B cell responses leading to increasing neutralising antibody titers, however increased disease severity is associated with higher viral loads and antibody titers (Le Bert et al., 2020). The magnitude of the acute T cell responses in Middle Eastern Respiratory Syndrome (MERS), a related $\beta$-coronavirus, is negatively associated with the magnitude of the $\mathrm{CD} 4^{+} \mathrm{T}$ cell response and the duration of illness and thus antigen loads (Mok et al., 2020, Zhao et al., 2017).

In a small family case study, children $(n=3)$ exposed to their SARS-CoV-2 infected 
108 infection was not able to be virologically confirmed (Tosif et al., 2020). Asymptomatic

109 infection may represent a large proportion of SARS-CoV-2 infections, particularly in

110 children. The immunological differences of cellular recruitment for children and adults has

111 not been sufficiently characterised to determine the immunological basis of differing

112 diseases severity and outcomes of COVID-19.

113 In Hong Kong, effective public health measures of track, trace, quarantine of

114 returned travellers and testing of quarantined close contacts has led to the identification of

115 RT-PCR confirmed asymptomatic infections, even in young children. In this study, we

116 assessed the balance of specificity, memory phenotype, cytokine quality and longitudinal

117 stability of SARS-CoV-2 T cell responses in children (aged 2-13 years old) and adults with

118 asymptomatic or symptomatic infection to address the role of T cells in the pathogenesis of

119 milder disease in children. 


\section{Materials and Methods}

\section{Study population and clinical samples}

122 Our study used samples from 24 children and 45 adults with RT-PCR confirmed SARS-

123 CoV-2 infection in Hong Kong (Table 1). The days after onset of symptoms (for

124 symptomatic infections) and days after first RT-PCR confirmation (for asymptomatic

125 infections) was noted. All symptomatic or asymptomatic RT-PCR confirmed infections were hospitalized. Heparinised blood was collected at hospital admission (range: 1-14 days post symptom onset and/or RT-PCR confirmed infection), at discharge (range: 6-60 days) and at regular intervals after discharge for convalescent and long-term memory (range: 61-180 days) (Figure 1A). We used samples from a total of 45 adults (mean \pm stdev: $43.1 \pm 13.7$,

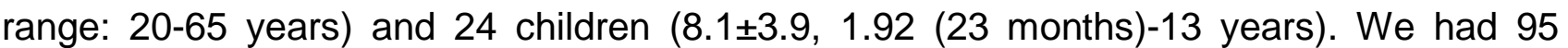

131 Iongitudinal samples from 46 subjects with 2 to 3 sampling time-points and 55 early acute

132 time-points samples (< day 14) (Figure 1A). Samples of comparable time-points were used 133 from children (32.5 $\pm 40.4,2-138$ days) and adults (28.9 $\pm 39.6,1-180$ days) (Table 1$)$.

The study was approved by the institutional review board of the respective hospitals, viz. Kowloon West Cluster (KW/EX-20-039 (144-27)), Kowloon Central / Kowloon East cluster (KC/KE-20-0154/ER2) and HKU/HA Hong Kong West Cluster (UW 20-273, UW20169), Joint Chinese University of Hong Kong-New Territories East Cluster Clinical

138 Research Ethics Committee (CREC 2020.229). All of patients provided informed consent.

139 The collection of SARS-CoV-2 seronegative adult negative control blood donors

140 (37.6 13.0 , 19-57 years) was approved by the Institutional Review Board of The Hong

141 Kong University and the Hong Kong Island West Cluster of Hospitals (UW16-254).

143 minutes upon testing. Peripheral blood mononuclear cells (PBMC) were isolated by Ficoll-

144 Paque (GE Healthcare) separation using Leucosep tubes (Greiner Bio-one) and

145 cryopreserved in liquid nitrogen for batched analysis. 


\section{SARS-CoV-2 overlapping peptide pools for T cell stimulation}

An overlapping peptide library was made covering the whole SARS-CoV-2 proteome with 20 amino acid (aa) length and 10 aa overlap (Genscript). The amino acid sequence of the peptide pools was based on $\beta$ CoV/Hong Kong/VM20001061/2020 strain (GISAID ID: EPI_ISL_412028). Peptides were dissolved in deionised water, 10\% acetic acid, or DMSO according to their biochemical properties and charge. A pool of 197 peptides representing Structural proteins: from S (1273aa, 127 peptides), N (419aa, 41 peptides), E (75aa, 7 peptides), M (222aa, 22 peptides), with a DMSO concentration of $0.6 \%$. The ORF1ab peptide pool consisted of 709 peptides for the NSP1-16 proteins (7096aa), with a DMSO concentration of $2.1 \%$. An accessory peptide pool of 69 peptides for the ORF3a (275aa, 27 peptides), ORF3b (43aa, 5 peptides), ORF6 (61aa, 6 peptides), ORF7a (121aa, 12 peptides), ORF7b (43aa, 3 peptides), ORF8 (121aa, 12 peptides), ORF10 (43aa, 3 peptides) proteins with a DMSO concentration of $0.2 \%$ (Figure 1B). Experimental controls included: cytomegalovirus (CMV) peptide pool (Grifoni et al., 2020) and PMA/ionomycin as positive controls, and for negative controls media alone and average DMSO control $(1.0 \%$ concentration) for background cytokine production (Supplementary Figure 1B). SARS-CoV2 peptide Megapools (Spike plus all pool, 467 peptides) for predicted MHC restricted peptides covering all proteins of the genome for $\mathrm{CD}^{+} \mathrm{T}$ cells and CMV from Grifoni et al. were used as initial positive controls (Grifoni et al., 2020).

\section{SARS-CoV-2-specific T cells by Intracellular Cytokine Staining (ICS)}

Cryopreserved PBMCs were thawed and re-stimulated with overlapping peptide pools representing the SARS-CoV-2 structural proteins, accessory proteins, or ORF1ab (300 $\mathrm{nM}$ ), DMSO (1\% in RPMI), CMV peptide pool, PMA/ionomycin (1\% in PBS) or RPMI alone for 6 hours at $37^{\circ} \mathrm{C}$. Golgi Plug (BD) containing Brefeldin A (1\% in PBS), and Golgi Stop (BD) containing Monensin ( $0.67 \%$ in PBS) was added at 2 hours during stimulation. Cells were stained with Zombie-NIR (all antibodies from Biolegend and clone used) followed by 
174 anti-human CD3-PE/Dazzle 594 (UCHT1), CD4-BV605 (OKT4), CD8-AlexaFluor700 (SK1),

175 CD107a-PacificBlue (H4A3), CCR5-PE (J418F1), CCR7-PerCP/Cy5.5 (G043H7) and

176 CD45RA-APC (HI100) and a dump channel containing CD19-BV510 (HIB19), CD56-

177 BV510 (HCD56) and CD14-BV510 (M5E2). Cells were then permeabilised and fixed (BD

178 Cytofix/cytoperm) and further stained for anti-human IFNy-FITC (4S.B3), IL-2-PECy7

179 (MQ1-17H12), TNF- $\alpha-B V 711$ (MAb11). Stained cells were acquired via flow cytometry

180 (AttuneNxT) and analysed by FlowJo v10 (Supplementary figure 1). Experiments were

181 repeated twice on independent samples.

182

\section{Immunostaining of Monocytes, T Follicular Helper (Tfh) cells and Plasmablasts}

Whole blood samples were stained with an antibody panel (all Biolegend and clone used), and live/dead Zombie-NIR to identify monocytes, Tfh and plasmablast responses (Supplementary Figure 2). The combined monocytes/plasmablast panel contained: antihuman CD16-PE (3G8), CD14-PerCPCy5.5 (M5E2), HLA-DR-BV605 (L243), CCR2-APC (K035C2), CD19-BV510 (HIB19), CD27-FITC (M-T271) and CD38-BV421 (HIT2). The Tfh panel contained: anti-human CD4-AlexaFluor700 (SK3), CXCR5-PerCPCy5.5 (J252D4), CD45RA-FITC (HI100), CCR6-BV605 (G034E3), CXCR3-APC (G025H7), PD-1-BV711 (EH12.2H7) and ICOS-PE (C398.4A). Cells were acquired by flow cytometry (AttuneNxT).

\section{Spikes-specific IgG quantification by Enzyme-linked immunosorbent assay (ELISA)}

Plates (Nunc MaxiSorp, Thermofisher Scientific) were coated with one representative coronavirus Spike protein at a time. Plates were coated with either $80 \mathrm{ng} / \mathrm{ml}$ of purified baculovirus-expressed Spike protein from 229E, NL63, HKU-1 and OC43 (SinoBiological). Plates were rinsed, blocked with 1\% FBS in PBS, incubated with 1:100 HI plasma diluted in $0.05 \%$ Tween-20/0.1\% FBS in PBS for 2 hours then rinsed again, and incubated for 2 hours with IgG-HRP (1:5000, G8-185; BD). HRP was revealed by stabilized hydrogen peroxide and tetramethylbenzidine (R\&D systems) for 20 minutes, stopped with $2 \mathrm{~N}$ 
201 sulphuric acid and absorbance values were recorded at $450 \mathrm{~nm}$ on a spectrophotometer

202 (Tecan Life Sciences).

\section{Statistical Analysis}

205 Statistical analysis was performed on Prism 9 (Graphpad). For two-way comparison, the 206 Wilcoxon signed-rank test (paired) or Mann-Whitney t-test (unpaired) was used. For 207 multiple-group comparisons, a Friedman (paired) or Kruskal-Wallis (unpaired) test, followed 208 by the Dunn-Bonferroni post-hoc test was used. The One sample Wilcoxon signed-rank 209 test was used for comparisons against a hypothetical value for fold changes. Correlations 210 were performed using the Spearman's test. To account for correlation due to multiple 211 measurements from the same patients, a linear random effects model was fitted 212 (Supplementary table 1). The model also tested the linear time trend by days after illness 213 onset, and potential differences by age, sex and symptomatic patients. Differences were 214 tested using Mann-Whitney test. Differences in baseline characteristics was detected with 215 the chi square test. Adjusted $p$ values $<0.05$ were considered statistically significant.

\section{Data availability statement}

218 The protein, peptide sequences and data that support the findings of this study are 219 available from the corresponding author upon request. The amino acid sequence of the 220 peptide pools was based on $\beta \mathrm{CoV} /$ Hong Kong/VM20001061/2020 strain (GISAID ID: 221 EPI_ISL_412028). Data from flow cytometry and ELISA IgG responses with background 222 subtracted are indicated, and representative flow cytometry plots are shown. 


\section{Results}

\section{Recent infection is associated with an increase of $\mathrm{CD4}^{+} \mathbf{T}$ cell responses to}

\section{5 structural proteins}

226 SARS-CoV-2 specific T cell responses were assessed from COVID-19 cases in children 227 and adults, and in adult negative controls. SARS-CoV-2 consists of 4 structural proteins, an 228 extensive ORF1ab which encodes 16 non-structural proteins, and 7 accessory proteins.

229 The relative expression of the structural proteins versus accessory and non-structural 230 proteins during SARS-CoV-2 virus replication may impact their immunogenicity. Cross231 reactivity with common cold viruses (Edridge et al., 2020) may also affect the magnitude of 232 T cell responses elicited. Due to limited cell numbers of our samples, peptide or protein 233 specific mapping was not possible. Therefore direct ex vivo $\mathrm{CD}^{+}$and $\mathrm{CD}^{+} \mathrm{T}$ cell 234 responses were assessed for overlapping peptide pools of structural, accessory and 235 ORF1ab proteins respectively, (Figure 1B) using IFNy production, a key anti-viral cytokine 236 as a read-out for specificity (Figure 1C). Paired samples from SARS-CoV-2 infected adults 237 at hospital admission (time 1) and discharge (time 2) showed an increase in structural 238 specific $\mathrm{IFNy}^{+} \mathrm{CD}^{+} \mathrm{T}$ cells (Figure $1 \mathrm{DF}$, fold change $\mathrm{p}=0.0005$ ) and to a lesser extent CD8 ${ }^{+} T$ cells (Figure 1EF, fold change $p=0.0230$ ).

The magnitude of SARS-CoV-2 specific CD4 ${ }^{+}$(Figure 1E) and CD8 ${ }^{+}$(Figure 1F) T

241 cells for structural, accessory and ORF1ab proteins was compared between adult patients 242 versus adult negative controls to establish assay specificity and cross-reactivity. We then 243 compared the $T$ cell responses of the adult infections versus paediatric infections to define 244 differences with age. The IFNy ${ }^{+} \mathrm{CD}^{+}{ }^{+} \mathrm{T}$ cell responses towards structural proteins of 245 SARS-CoV-2 were significantly increased in adults (mean \pm stdev: $0.0533 \pm 0.0549 \%$ ), 246 compared to both children $(0.0240 \pm 0.0292 \%, p=0.0031)$ and adult negative controls $247(0.0013 \pm 0.0005 \%, p<0.01)$ (Figure $1 G)$. The majority of infected adults $(94.3 \%)$ mounted a 248 structural-specific $\mathrm{CD}^{+} \mathrm{T}$ cell responses (above DMSO background) (Figure 1I), whilst only $79.4 \%$ of children and $50 \%$ of adult negative controls had such responses (Figure 1I). 
250 Despite the higher magnitude of responses to structural proteins in infected adults than

251 children, the proportion of responders against each peptide pool was not significantly

252 different between adults and children, except for structural CD8 ${ }^{+}$responses (Figure 1I).

253 Therefore, the majority of our later analyses focusses on structural specific $T$ cell 254 responses.

The accessory-specific $\mathrm{CD}^{+} \mathrm{T}$ cell response was comparable in infected children, infected adults and adult negative controls (Figure 1G). In infected adults, the structuralprotein-specific $\mathrm{CD}^{+} \mathrm{T}$ cell responses (86.6\%) contributed most to the SARS-CoV-2 specific response (Figure $1 \mathrm{~J})$, than ORF1ab (9.6\%) and accessory (3.8\%) responses. By contrast, the SARS-CoV-2 specific response in infected children's CD4 ${ }^{+} \mathrm{T}$ cell responses were dominated more by ORF1ab (51.8\%) than structural specific responses (43.7\%). Responses from adult negative controls that recognised SARS-CoV-2 peptides were predominately specific for accessory peptides (90.1\%), however the total response was very low in magnitude, at only $0.013 \pm 0.02 \%$ of $C D 4^{+} \mathrm{T}$ cells (Figure $1 \mathrm{~J}$ ).

Infected adults did not have significantly higher $\mathrm{CD} 8^{+} \mathrm{T}$ cell responses compared to adult negative controls (Figure $1 \mathrm{H}$ ) indicating cross-reactivity and little amplification of SARS-CoV-2 CD8 ${ }^{+} \mathrm{T}$ cell responses by infection (Figure 1EF). But infected children had significantly reduced $\mathrm{CD}^{+} \mathrm{T}$ cell responses compared to infected adults for structural and ORF1ab responses (Figure $1 \mathrm{H})$.

However baseline differences exist between adults and children for non-specific $T$ 270 cell activation (Lewis et al., 1991, Rudolph et al., 2018, Booth et al., 2014). The baseline 271 activation (by DMSO) and overall maximum activation (by PMA/ionomycin) is lower in 272 children, and responsiveness significantly increased with age (Supplementary Figure 2 A273 D). Adult negative controls had comparable background IFNy induction compared to 274 infected adults (Supplementary Figure 2A), However, the maximum responses by 275 PMA/ionomycin was lower in $\mathrm{CD}^{+} \mathrm{T}$ cells and higher in $\mathrm{CD}^{+} \mathrm{T}$ cells in negative control 276 adults compared to infected adults (Supplementary Figure 2B), which may indicate $T$ cell 
activation is refractory based on recent infection (Crawford et al., 2013). Normalisation of

278 structural specific T cells by \% of maximum PMA/ionomycin responses shows comparable

279 responses across all groups (Supplementary Figure 2F). However the fine specificity of 280 identifying low frequency antigen specific $T$ cells is obscured, therefore $T$ cell responses

281 should be considered directly ex vivo with background subtracted not normalised for 282 maximum activation. There was a significant correlation between PMA/ionomycin and 283 structural specific $C D 4^{+} \mathrm{T}$ cell IFNy production $(r=0.6384, p=0.0001$, Supplementary Figure $2 \mathrm{G})$, but not $\mathrm{CD} 8^{+} \mathrm{T}$ cell responses $(\mathrm{r}=0.2568, \mathrm{p}=0.1707$, Supplementary Figure $2 \mathrm{H})$.

Furthermore, stratification of subjects for asymptomatic and symptomatic infection did not reveal any further significant differences for $T$ cell response magnitude

287 (Supplementary Figure 3AB) or contribution of peptide specificities (Supplementary Figure 3CD) between controls and COVID-19 adults and children.

\section{Recruitment of early cellular responses}

291 Coordination of the early acute response to SARS-CoV-2 infection is important to drive 292 innate responses (Zhang et al., 2021), and early antibody production (Thevarajan et al., 293 2020) for improved patient outcomes. Therefore, we assessed the recruitment and 294 activation of monocytes, total Tfh cells and plasmablasts (also known as antibody 295 producing cells) during acute $(<14$ days post infection) SARS-CoV-2 infection 296 (Supplementary Figure 4). The total monocytes showed reduced responses in children 297 compared to infected adults (Supplementary Figure 4B), furthermore children had reduced 298 inflammatory type monocytes (Supplementary Figure 4C), where these have been found to 299 also be elevated in COVID-19 patients, but lower in severe outcomes in adults (Zhang et 300 al., 2021, Mann et al., 2020). Meanwhile, infected children and adults showed comparable 301 levels of monocyte recruitment from bone marrow (CCR2) compared to infected adults 302 (Supplementary Figure 4D). 
early antibody production by plasmablasts is associated with seroconversion (Pilkinton et al., 2017). The early activated $\left(\mathrm{ICOS}^{+} \mathrm{PD}-1^{+}\right)$total Tfh response was significantly increased in infected children compared to adults and negative controls (Supplementary Figure 4G), whilst plasmablast responses were increased in both children and adults compared to negative controls showing B cell recruitment with infection (Supplementary Figure 4H).

\section{T cell responses increase with time post infection and age}

311 Longitudinal sample collection up to 180 days post infection enabled us to determine the 312 trend of $\mathrm{T}$ cell responses with time post infection. Long-term stability of durable $\mathrm{T}$ cell 313 immunity is likely important to minimise the symptom severity of reinfection with SARS-

314 CoV-2. The CD4 ${ }^{+} \mathrm{T}$ cell response to structural peptides had stable responses post infection 315 (Figure 2A) $(r=0.1475, p=0.2265)$, whilst structure specific CD8 $^{+} \mathrm{T}$ cell responses had a 316 moderate significant trend for increased responses with time (Figure 2B) $(r=0.4194$, $317 \mathrm{p}=0.0003)$. This was also reflected in the acute fold changes of CD4 ${ }^{+}$and $\mathrm{CD}^{+} \mathrm{T}$ cell 318 responses (Figure $1 \mathrm{~F}$ ), which indicates the $\mathrm{CD}^{+} \mathrm{T}$ cell response is recruited early during 319 SARS-CoV-2 infection (Figure 1D), the CD8 ${ }^{+}$T cell response takes more time to build up with time post-infection. Furthermore, there was no difference in T cell exhaustion (by PD-1 expression) between infected adults and children at either acute or memory responses (Supplementary Figure 5).

The fold change of response magnitude for paired acute responses ( $<14$ days) to memory time-points (>14 days) (Figure 2CD), showed comparable fold-changes in children and adults for $\mathrm{CD}^{+}$or $\mathrm{CD}^{+} \mathrm{T}$ cell response to most viral proteins. Only accessory-specific $\mathrm{CD}^{+} \mathrm{T}$ cell responses had a significant decrease in infected children (Figure 2D). Whilst the acute structural specific $\mathrm{CD}^{+} \mathrm{T}$ cell response was significantly increased in adults compared to negative controls (Figure 2E), the memory $\mathrm{CD}^{+}$and $\mathrm{CD}^{+} \mathrm{T}$ cell response were significantly lower in children compared to infected adults (Figure 2EH), resulting in a 
trend for significantly increased $\mathrm{T}$ cell responses with age (Figure 2FIJ), excluding acute

$\mathrm{CD}^{+} \mathrm{T}$ cell responses (Figure $2 \mathrm{G}$ ).

The difference in magnitude of $T$ cell responses with age and time indicates functional differences in $\mathrm{T}$ cell recruitment and differentiation, therefore we assessed cytokine polyfunctionality and memory phenotypes. Cytokine polyfunctionality is associated with increased protection from infection for multiple viruses (Lichterfeld et al., 2004, Sridhar et al., 2013), and associated with cellular division and terminal differentiation (Denton et al., 2011). Whilst differentiation of $T$ cell memory phenotypes occurs early during infection and can reflect the extent of inflammation (Kretschmer et al., 2020), impacting recall capacity long-term (Kinjyo et al., 2015) to infected tissues (Weninger et al., 2001).

Cytokine polyfunctionality of structure-specific $T$ cells (Figure $3 A B$ ) was comparable between adults and children at acute ( $<14$ days), convalescent (15-60 days) or memory (61-180 days) time points (Figure 3C), therefore on a per cell basis adults and children had comparable cytokine responses. The phenotype of structure-specific $T$ cells at memory time points (Figure 3D), however showed that children had reduced $T$ effector memory (TEM) $\mathrm{CD}^{+} \mathrm{T}$ cells compared to infected adults (Figure 3E). The phenotype of structurespecific CD8 ${ }^{+} \mathrm{T}$ cells was comparable (Figure $3 \mathrm{~F}$ ).

\section{Prior common cold coronavirus immunity and cellular responses}

349 The level of coronavirus Spike-specific IgG was determined at early time points ( $<14$ days) of SARS-CoV-2 infection, to determine if pre-existing immunity impacted T cell responses.

351 The magnitude of $\alpha$-coronavirus 229E and NL63-specific IgG was comparable between infected children and adults and adult negative controls (Figure 4A), whilst $\beta$-coronavirus

353 HKU-1 and OC43-specific IgG was significantly lower in infected children than infected 354 adults (Figure 4B). Furthermore, there was no difference in OC43-IgG responses between symptomatic or asymptomatic infections, with significance only being seen between

356 symptomatic adults and children (Figure 4C). There was a significant correlation of OC43- 
IgG responses with age (Figure 4D) $(r=0.6466, p=0.0002)$. However there was no direct significant correlation between OC43-IgG responses and structure-specific CD4 ${ }^{+}$ $(p=0.1027$, Figure $4 E)$ or $\mathrm{CD}^{+} \mathrm{T}$ cells $(\mathrm{p}=0.9729$, Figure $4 \mathrm{~F})$. Similar trends of a lack of significant correlation were seen for $\mathrm{HKU}-1 \mathrm{lgG}$ responses and acute $\mathrm{CD}^{+}{ }^{+} \mathrm{T}$ cell responses $(r=0.3085, p=0.1034$, data not shown), despite other reports in uninfected adults (Tan et al., 2021). However, there was a borderline moderate negative correlation between OC43-IgG and early acute activated Th responses (Figure 4G) $(r=-0.3310, p=0.0854)$.

\section{Discussion}

SARS-CoV-2 infection of children is associated with milder clinical outcomes than adults, and the immune mechanisms are unknown. Several immune mechanism have been proposed to explain these differences such as innate cell recruitment and impairment by autoantibodies (Wang et al., 2020), mobilisation of antibody responses, differing levels of pre-existing cross-reactive immunity by common cold coronavirus exposure (Anderson et al., 2020) or baseline total IgM levels (Selva et al., 2020). However, the SARS-CoV-2 T cell compartment in children has so far been under studied (Tosif et al., 2020). Viral loads (Jones et al., 2020) and neutralising antibody titers (Weisberg et al., 2021, Lau et al., 2021) are reportedly comparable when age is accounted for, however data is more limited in children. Viral loads, neutralising antibody titers (Garcia-Beltran et al., 2020), and T cell responses (Peng et al., 2020) impact clinical severity of COVID-19.

Cross-reactive $\mathrm{T}$ cell responses in unexposed adults have been mapped to have been NSPs of ORF1ab and Spike (Grifoni et al., 2020), whilst recent infection boosts structural Spike and N specific T cells (Le Bert et al., 2020, Mateus et al., 2020). The specificity of SARS-CoV-2 antibody landscapes differs in infected children to adults (Weisberg et al., 2021, Hachim et al., 2021), with an increased contribution by accessory proteins (Hachim et al., 2021), whilst the ORF1ab response is under characterised. SARSCoV-2 antibody landscapes indicate that the specificity and balance of the adaptive 
immune responses in children is different to adults. We sought to determine the balance of

SARS-CoV-2 specific T cell responses in adults and children as infection progresses to

recovery for long-term memory, whilst considering $T$ cell specificity for the virion (structural proteins) and virus replication (ORF1ab and accessory proteins) as a surrogate for viral replication and pathogenesis.

Overall, we found total IFNy CD4 ${ }^{+}$and $\mathrm{CD} 8^{+} \mathrm{T}$ cell responses are significantly lower

in SARS-CoV-2 infected children than adults against the viral structural proteins, and in

$\mathrm{CD}^{+} \mathrm{T}$ cells against ORF1ab proteins. Whilst there were no negative control PBMCs available in our study from uninfected children for direct comparison as it is difficult to obtain blood from healthy children, pairwise comparison between infected adults and children showed markedly different SARS-CoV-2 T cell responses. However, we and others (Lewis et al., 1991, Chipeta et al., 1998, Rudolph et al., 2018, Booth et al., 2014), found that the capacity of children's T cells to respond to polyclonal non-specific activation is also lower. Whereas vaccination with live influenza vaccines boosts $T$ cell responses in children and not adults (He et al., 2006), this may be due to differences in prior immunity through infection (Shannon et al., 2019), resulting in qualitative differences in antigen experienced $\mathrm{CD}^{+} \mathrm{T}$ cell responses in children. As IFNy T cell induction increases with age, so does exposure to viruses. Therefore the differences in SARS-CoV-2 T cell magnitude may be due to inherent differences between children and adult $T$ cell threshold for activation. This has different consequences in different scenarios of a pandemic virus compared to vaccination building on prior memory. For example, there is an increased fold change of children's T cell responses compared to adults during live attenuated influenza vaccination ( $\mathrm{He}$ et al., 2006), whilst we found lower SARS-CoV-2 T cell response magnitudes in children, their fold changes and polyfunctional cytokines of the $T$ cell responses was comparable between adults and children. Therefore there is equal 
410 baseline levels of cross-reactive responses to recruit from and inherent differences in

411 thresholds of activation.

A difference in $\mathrm{T}$ cell memory phenotypes showed greater bias towards $\mathrm{T}$ cell

413 effector memory in adults compared to children. Along with total response and 414 polyfunctional cytokine production, this indicates that on a per $\mathrm{T}$ cell basis the $\mathrm{T}$ cell 415 response in children is less antigen experienced and matured than adults, and may be due 416 to different levels of prior immunity to seasonal human coronaviruses. This was also found 417 by smaller magnitude memory $T$ cell responses in children than adults, which may imply a 418 weaker long-term memory response in children potentially impacting outcomes at 419 reinfection. Indeed, we found significantly lower levels of $\beta$-coronavirus specific antibodies 420 in infected children than adults, and there was a significant trend for both increased SARS421 CoV-2 specific $T$ cell responses and OC43-specific IgG with increasing age. Recently, 422 similar results were found in healthy adults as HKU-1 IgG showed an increasing trend with 423 SARS-CoV-2 specific T cell responses of memory phenotype in uninfected adults (Tan et 424 al., 2021). A borderline trend for decreasing acute activated Tfh with higher OC43-specific 425 IgG levels also suggests a greater importance $\mathrm{CD}^{+} \mathrm{T}$ cell recruitment in more 426 immunologically naïve settings, and as $\beta$-coronavirus specific IgG levels increase there is a 427 decreasing drive for Tfh recruitment. Only the quantification of baseline T cell responses 428 specific for common cold viruses and subsequent exposure to SARS-CoV-2 in further 429 studies, such as in human cohort transmission settings or animal models, will determine if 430 prior $\beta$-coronavirus immunity, based on T or B cells, has a protective role in COVID-19. The quality of $\mathrm{T}$ cell responses, assessed by SARS-CoV-2 specific $\mathrm{T}$ cell 432 polyfunctional cytokine production, was equivalent between children and adults, reflecting 433 division and terminal differentiation. Furthermore, $T$ cell exhaustion, assessed by 434 expression of PD-1 is higher in COVID-19 patients with expression increasing with severity 435 (Diao et al., 2020). While we also see differences in infected and negative adults, infected 436 adults and children have equivalent PD-1 levels on T cells. Therefore, whilst SARS-CoV-2 
specific $T$ cell responses in children are reduced they comparably activated/exhausted (by

PD-1 expression). The matched quality of response but higher threshold for IFNY production by $\mathrm{T}$ cells in children may drive a less inflammatory environment that promotes more mild outcomes in children. Lower levels of total and inflammatory monocytes, may

441 further contribute to a less inflammatory environment. However paradoxically lower 442 inflammatory monocytes are associated with both healthy individuals and patients with 443 severe COVID-19 infections (Mann el al., 2020; Zhang et al., 2021), therefore the timing of 444 monocyte recruitment is likely important. There was a different recruitment of innate and 445 adaptive cellular responses in adults and children during SARS-CoV-2 infection. Children 446 had increased Tfh recruitment, comparable plasmablast responses, but reduced 447 monocytes, specific $\mathrm{CD} 4^{+}$and $\mathrm{CD} 8^{+} \mathrm{T}$ cell responses, in both magnitude and proportion of 448 responders. The inflammatory milieu is likely drivers of innate and adaptive cell recruitment, 449 and indicates differences between adults and children across the anti-viral immune 450 response.

T cell responses can be quantified by numerous methods besides IFNy induction by peptide stimulation as adopted in our study, such as proliferation (Ki67) and activation induced markers (AIM, such as 41-BB/CD40L, OX40, CD25 etc) (Grifoni et al., 2020), antigen experience (CD69, CD44), or the production Th2 cytokines such as IL-4. In addition to functional assays, $\mathrm{T}$ cell responses can be quantified by $\mathrm{T}$ cell receptor binding to cognate peptide MHC by dimer/tetramers (Peng et al., 2020). However, known SARSCoV-2 epitopes are currently limited and the HLA should be defined within donors. The induction of AIM for Tfh responses and the $\mathrm{CD}^{+}{ }^{+} \mathrm{T}$ cell profile across different cell types (Th17, Treg etc), should also be assessed in future studies. We found that children had 460 increased activated Tfh responses but lower IFNy ${ }^{+} \mathrm{CD}^{+} \mathrm{T}$ cells, therefore the $\mathrm{CD} 4^{+} \mathrm{T}$ cell compartment is modulated by SARS-CoV-2 infection, and more so than the CD8 ${ }^{+} \mathrm{T}$ cell response which is lagging behind the acute stage. In addition more variables can be assessed by high dimensional flow cytometry or RNAseq approaches, and further 
mechanistic studies are needed to define the basis of immunological differences between $\mathrm{T}$ cell responses of children and adults indicated in our study.

Adult negative controls had significantly lower structural/ORF1ab $\mathrm{CD}^{+} \mathrm{T}$ cell responses but comparable $\mathrm{CD}^{+} \mathrm{T}$ cell responses to infected adults. This was also reflected in greater $\mathrm{CD}^{+} \mathrm{T}$ cell increases at acute timepoints of infection, and delayed $\mathrm{CD} 8^{+} \mathrm{T}$ cell increases with time, indicating $\mathrm{CD} 4^{+} \mathrm{T}$ cell responses play a greater role in the early responses to SARS-CoV-2 infection. The contribution of different virion structural and non-structural proteins reflects MHC processing access during viral replication, whereby

$472 \mathrm{MHCll}$ access to structural proteins elicited substantial $\mathrm{CD}^{+} \mathrm{T}$ cell responses in adults, in 473 children the $\mathrm{CD}^{+} \mathrm{T}$ cell response was predominantly ORF1ab specific. The imbalance of 474 peptide specificities for non-structural proteins for children's CD4 ${ }^{+} \mathrm{T}$ cell compartment may 475 indicate either different virus replication and pathogenesis at the cellular level or incomplete 476 recruitment of de novo $\mathrm{CD}^{+}{ }^{+} \mathrm{T}$ cell responses. Previously, in MERS-CoV infection, the 477 magnitude of the $\mathrm{CD}^{+} \mathrm{T}$ cell response is proportional to virus replication and duration of 478 illness (Zhao et al., 2017). This is consistent with the mild outcomes of COVID-19 in 479 children and reduced T cell responses reported here in our study of mild and asymptomatic 480 SARS-CoV-2 infection. We cannot attribute the differences in T cell response magnitude 481 with severity of illness in children to adults, unlike others reports (Peng et al., 2020), as the 482 majority of both infections we studied are mild or asymptomatic. Therefore children have 483 reduced SARS-CoV-2 T cell responses due to lower baseline immune activation, and 484 further research is still needed to discern the protective role of T cells in COVID-19. 


\section{Figure legends}

Figure 1 - Children have lower $\mathrm{CD4}^{+}$and $\mathrm{CD} 8^{+} \mathrm{T}$ cell responses than adults with COVID-19. $\mathrm{CD}^{+} \mathrm{T}$ cell responses are predominantly ORF1ab specific, while children and adults have different $\mathrm{CD}^{+}{ }^{+} \mathrm{T}$ cells targets. (A) Heparinised blood samples for PBMCs were collected from COVID-19 patients in Hong Kong during the course of infection and recovery. (B) Overlapping peptide pools of the whole SARS-CoV-2 proteome were generated to represent ORF1ab, Structural, and Accessory proteins with amino acids (aa) and peptides (p) per protein shown. (C) PBMCs were stimulated with peptide pools or a DMSO control and IFNy production of $\mathrm{CD}^{+}$and $\mathrm{CD}^{+} \mathrm{T}$ cells measured by flow cytometry. Paired time points at hospital admission and discharge (time 1: mean $7.25+/-$ stdev 4.6 days post infection, range 3 to 18 ; time 2: mean $13.4+/$-stdev 4.4, range 6 to 21) for paired background (DMSO) subtracted structural specific IFNy response of CD4 ${ }^{+}$(D) and $\mathrm{CD}^{+}(\mathrm{E}) \mathrm{T}$ cells ( $\mathrm{n}=20$ adults). Wilcoxon test was used to determine differences ${ }^{* *} p<0.01$. Dotted lines represent limit of detection following background subtraction (CD4=0.0019, CD8=0.00047). (F) The fold change of paired structural specific CD4 ${ }^{+}$and $\mathrm{CD}^{+} \mathrm{T}$ cells responses from $(\mathrm{D}, \mathrm{E})$, significance calculated using One sample Wilcoxon test against a theoretical median of 1 . Dotted line at 1 indicates no fold change. The SARSCoV-2 $\mathrm{CD}^{+}(\mathrm{G})$ or $\mathrm{CD}^{+}(\mathrm{H})$ T cell responses of COVID-19 children $(n=34)$, adults $(n=36)$ (mean \pm stdev: $42 \pm 44$, range $1-180$ days) and negatives $(n=10)$. Data are displayed as individual responses to each peptide pool with IFNy production to paired DMSO subtracted. The dotted line represents the lower limit of detection, determined as the smallest calculated value above the DMSO background response (IFNy of $\mathrm{CD}^{+}=0.00017 \%$, IFNy of $\mathrm{CD}^{+}=0.00011 \%$ ). Comparisons between groups were performed using Mann-Whitney test with the effect of the sampling time accounted for, statistical differences are indicated by ${ }^{*} p<0.01,{ }^{* *} p<0.001,{ }^{* * *} p=0.0001$. Values above the limit are used to classify participants as responders and presented as a percentage with the numbers of responders in brackets (I). Differences between children $(n=34)$ and adults $(n=36)$ from all time points ( 1 to 180 days 
512 post symptom onset) were determined by Fisher's exact test and displayed in the adults

513 column where ${ }^{*} \mathrm{p}<0.05$. Pie charts show the proportion of total $\mathrm{IFNy}^{+} \mathrm{CD} 4^{+}(\mathrm{J})$ and $\mathrm{CD} 8^{+}$

514 (K) SARS-CoV-2 responses with DMSO subtracted in children $(n=34)$, adults $(n=36)$ and

515 negatives $(n=10)$ (from $G, H$ ). Values below the limit of detection assigned the value of 0.

517 Figure 2: SARS-CoV-2 specific CD4+ and CD8+ T cell responses increase over time

518 and age. Correlation of IFNy responses for $\mathrm{CD}^{+}(\mathrm{A})$ and $\mathrm{CD}^{+}(\mathrm{B}) \mathrm{T}$ cells against the

519 structural peptide pool with children (red) $(n=34)$ and adults (black) $(n=36)$ (with

520 background IFNy production to DMSO subtracted), against days post symptom onset.

521 Black dotted lines represent the limit of detection (IFNy of $\mathrm{CD}^{+}=0.000167$ (A), IFNy of

$\left.522 \mathrm{CD}^{+}=0.00011(\mathrm{~B})\right)$. Fold change of IFNy $\mathrm{CD}^{+}(\mathrm{C})$ and $\mathrm{CD}^{+}(\mathrm{D}) \mathrm{T}$ cell responses were

523 calculated as the later time point (mean \pm stdev: $32.8 \pm 35.7$ days, range: 9-138) over

524 admission time point responses (mean \pm stdev: $7.6 \pm 4.2$, range: $2-15)$ ) in response to the

525 structural, accessory and ORF1ab peptide pools in children and adults from two

526 independent experiments (children $n=14$, adults $n=14$ ). One sample Wilcoxon tests were

527 used for determining significance of fold changes, were ${ }^{*} p<0.05$. Acute (samples $<14$ days

528 post symptom onset, mean \pm stdev: $8.0 \pm 3.8$, range: $1-14, n=22$ children, $n=14$ adults) (E-G),

529 and convalescent/memory $(\mathrm{H}-\mathrm{J})$ (mean \pm stdev: $70.5 \pm 41.9$, range: $15-180$ days post

530 symptom onset, $n=12$ children, $n=22$ adults) IFNy structural specific $(F, I) C D 4^{+}$and $(G, J)$

$531 \mathrm{CD}^{+} T$ cell responses and negative controls $(n=10)$. For statistical comparisons between

532 children and adults, or adults and negatives, Mann-Whitney tests were performed, ${ }^{*} p<0.05$,

$533{ }^{* *} \mathrm{p}<0.01,{ }^{* * *} \mathrm{p}<0.001,{ }^{* * *} \mathrm{p}<0.0001$. The magnitude of the acute (from E) and memory

534 (from $\mathrm{H}$ ) structural IFNy $\mathrm{CD}^{+}(\mathrm{F}, \mathrm{I})$ and $\mathrm{CD}^{+}(\mathrm{G}, \mathrm{J}) \mathrm{T}$ cell response with age. $\mathrm{R}$ values are

535 calculated using Spearman's correlation and ${ }^{*} \mathrm{p}<0.05,{ }^{* *} \mathrm{p}<0.01,{ }^{* * *} \mathrm{p}<0.001,{ }^{* * * *} \mathrm{p}<0.0001$.

536 Blue lines of linear regression represent the overall trend, and blue dotted lines show the

537 upper and lower $95 \%$ confidence intervals. All data points are individual responses minus

538 paired background IFNy response to a DMSO control. 
Figure 3 - Cytokine polyfunctional quality is comparable in COVID-19 children and

541 FACS plots of TNFa and IL2 producing IFNy ${ }^{+} \mathrm{CD}^{+}$and $\mathrm{CD}^{+} \mathrm{T}$ cells of children (red) and 542 adults (black) at acute ( $\mathrm{d}<14)(\mathrm{A})$ and memory (child: 118 days, adult: 94 days) (B) time 543 points. (C) The proportion of IFNy producing $\mathrm{CD}^{+}$and $\mathrm{CD} 8^{+} \mathrm{T}$ cells which are single, 544 double or triple cytokine producers at acute ( $<14$ days), convalescent (15-60 days) or 545 memory (61-180 days) time points post symptom onset. Kruskal Wallis test for multiple 546 comparisons was carried out to compare each group between children and adults. (D) 547 Representative FACS plots showing memory phenotypes of $\mathrm{IFNy}^{+} \mathrm{CD}^{+}$and $\mathrm{CD} 8^{+} \mathrm{T}$ cells 548 based on expression of CCR7 and CD45RA. Sections are T effector memory (TEM), 549 central memory (TCM), terminal effector memory (TeEM) or naïve (TN). Memory 550 phenotype responses in $\mathrm{IFNY}^{+} \mathrm{CD}^{+}(\mathrm{E})$ and $\mathrm{CD}^{+}(\mathrm{F}) \mathrm{T}$ cells of responders at later time 551 points (15-180 days post symptom onset). Comparisons between children $(n=15)$ and 552 adults $(n=20)$ in each group was performed using Mann-Whitney test, ${ }^{*} p<0.05$.

Figure 4 - Previous exposure to common cold beta coronaviruses and T cell responses. Total IgG responses to the Spike protein $(\mathrm{S} 1+\mathrm{S} 2)$ of common cold a (229E, NL63) (A) and $\beta$ (HKU1, OC43) (B) coronaviruses measured by ELISA from acute time points (mean \pm stdev: $8 \pm 3.8$, range: $2-14$ days post infection). (C) Stratification of OC43 IgG response by symptomatic (closed circles, $n=8$ children, $n=8$ adults) and asymptomatic (open circles, $n=8$ children, $n=5$ adults). (A-C) Data is representative of individual donor responses with background subtracted (non-specific protein block), and displayed with the median, upper and lower quartiles and minimum and maximum. Comparison between children ( $n=15)$ and adults $(n=14)$ or adults negative controls $(n=10)$ was performed using Mann-Whitney test where ${ }^{* *} p<0.01,{ }^{* * *} p<0.001,{ }^{* \star *} p<0.0001$. (C) Multiple comparisons between symptomatic and asymptomatic adults and children were carried out using 
linear regression represents the overall trend, and blue dotted lines show the upper and

lower $95 \%$ confidence intervals. Correlation of structural SARS-CoV-2 specific IFNy ${ }^{+} \mathrm{CD}^{+}$

(E) or $\mathrm{CD}^{+}(\mathrm{F}) \mathrm{T}$ cell responses and OC43 Spike IgG. (G) Correlation of activated Tfh and

OC43 Spike IgG. R values are determined using Spearman's correlation and statistical significant correlations displayed as ${ }^{* *} p<0.001$. Dotted lines indicate the limit of detection following subtraction of DMSO from T cell response.

Acknowledgements: This study was partly supported by the Theme based Research

Grants Scheme (T11-712/19-N), Health and Medical Research Fund (HMRF COVID190115 and COVID-190126), National Institutes of Allergy and Infectious Diseases,

National Institutes of Health (USA) (HHSN272201400006C and U01Al151810). We thank

Daniela Weiskopf, Jose Barrera, Shane Crotty and Alessandro Sette from La Jolla Institute,

USA, for providing SARS-CoV-2 peptide Megapools. This project utilised an Invitrogen Attune flow cytometer assisted by the Pasteur Foundation Asia.

Author contributions: CAC performed experiments. CAC, APYL, AH, NK, SAV designed experiments. MYWK, WHC, YSY, SSC OTYT, DSCH provided clinical information and supplied clinical samples, processed by FNLM coordinated by SMSC. EHYL performed

584 further analysis. CAC, LP, JSMP and SAV designed the study. CAC, APYL, AH, NK, LP, JSMP, SAV interpreted results and wrote the manuscript.

\section{Competing interests}

588 None to declare.

\section{References}

ADDETIA, A., CRAWFORD, K. H. D., DINGENS, A., ZHU, H., ROYCHOUDHURY, P., 
Neutralizing Antibodies Correlate with Protection from SARS-CoV-2 in Humans during a Fishery Vessel Outbreak with a High Attack Rate. J Clin Microbiol, 58.

ANDERSON, E. M., GOODWIN, E. C., Verma, A., AREVAlO, C. P., BOLTON, M. J., WEIRICK, M. E., GOUMA, S., MCALLISTER, C. M., CHRISTENSEN, S. R., WEAVER, J., HICKS, P., MANZONI, T. B., ONIYIDE, O., RAMAGE, H., MATHEW, D., BAXTER, A. E., OldRIDGE, D. A., GREENPLATE, A. R., WU, J. E., ALANIO, C., D'ANDREA, K., KUTHURU, O., DOUGHERTY, J., PATTEKAR, A., KIM, J., HAN, N., APOSTOLIDIS, S. A., HUANG, A. C., VELLA, L. A., WHERRY, E. J., MEYER, N. J., CHERRY, S., BATES, P., RADER, D. J. \& HENSLEY, S. E. 2020. Seasonal human coronavirus antibodies are boosted upon SARS-CoV-2 infection but not associated with protection. medRxiv.

BACHER, P., ROSATI, E., ESSER, D., MARTINI, G. R., SAGGAU, C., SCHIMINSKY, E., DARGVAINIENE, J., SCHRODER, I., WIETERS, I., KHODAMORADI, Y., EBERHARDT, F., VEHRESCHILD, M., NEB, H., SONNTAGBAUER, M., CONRAD, C., TRAN, F., ROSENSTIEL, P., MARKEWITZ, R., WANDINGER, K. P., AUGUSTIN, M., RYBNIKER, J., KOCHANEK, M., LEYPOLDT, F., CORNELY, O. A., KOEHLER, P., FRANKE, A. \& SCHEFFOLD, A. 2020. Low-Avidity CD4(+) T Cell Responses to SARS-CoV-2 in Unexposed Individuals and Humans with Severe COVID-19. Immunity, 53, 1258-1271 e5.

BLANCO-MELO, D., NILSSON-PAYANT, B. E., LIU, W. C., UHL, S., HOAGLAND, D., MOLLER, R., JORDAN, T. X., OISHI, K., PANIS, M., SACHS, D., WANG, T. T., SCHWARTZ, R. E., LIM, J. K., ALBRECHT, R. A. \& TENOEVER, B. R. 2020. Imbalanced Host Response to SARS-CoV-2 Drives Development of COVID-19. Cell, 181, 1036-1045 e9.

BOOTH, J. S., TOAPANTA, F. R., SALERNO-GONCALVES, R., PATIL, S., KADER, H. A., SAFTA, A. M., CZINN, S. J., GREENWALD, B. D. \& SZTEIN, M. B. 2014. Characterization and functional properties of gastric tissue-resident memory $T$ cells from children, adults, and the elderly. Front Immunol, 5, 294.

CELE, S., GAZY, I., JACKSON, L., HWA, S.-H., TEGALLY, H., LUSTIG, G., GIANDHARI, J., PILLAY, S., WILKINSON, E., NAIDOO, Y., KARIM, F., GANGA, Y., KHAN, K., BALAZS, A. B., GOSNELL, B. I., HANEKOM, W., MOOSA, M.-Y. S., LESSELLS, R. J., DE OLIVEIRA, T. \& SIGAL, A. 2021. Escape of SARS-CoV-2 501Y.V2 variants from neutralization by convalescent plasma. medRxiv, 2021.01.26.21250224.

CHAN, P. K. S., LUI, G., HACHIM, A., KO, R. L. W., BOON, S. S., LI, T., KAVIAN, N., LUK, F., CHEN, Z., YAU, E. M., CHAN, K. H., TSANG, C. H., CHENG, S. M. S., CHU, D. K. W., PERERA, R., HO, W. C. S., YEUNG, A. C. M., CHOW, C., POON, L. L. M., 

VALKENBURG, S. A., HUI, D. S. C. \& PEIRIS, M. 2020. Serologic Responses in Healthy Adult with SARS-CoV-2 Reinfection, Hong Kong, August 2020. Emerg Infect Dis, 26, 3076-3078.

CHANDRASHEKAR, A., LIU, J., MARTINOT, A. J., MCMAHAN, K., MERCADO, N. B., PETER, L., TOSTANOSKI, L. H., YU, J., MALIGA, Z., NEKORCHUK, M., BUSMANSAHAY, K., TERRY, M., WRIJIL, L. M., DUCAT, S., MARTINEZ, D. R., ATYEO, C., FISCHINGER, S., BURKE, J. S., SLEIN, M. D., PESSAINT, L., VAN RY, A., GREENHOUSE, J., TAYLOR, T., BLADE, K., COOK, A., FINNEYFROCK, B., BROWN, R., TEOW, E., VELASCO, J., ZAHN, R., WEGMANN, F., ABBINK, P., BONDZIE, E. A., DAGOTTO, G., GEBRE, M. S., HE, X., JACOB-DOLAN, C., KORDANA, N., LI, Z., LIFTON, M. A., MAHROKHIAN, S. H., MAXFIELD, L. F., NITYANANDAM, R., NKOLOLA, J. P., SCHMIDT, A. G., MILLER, A. D., BARIC, R. S., ALTER, G., SORGER, P. K., ESTES, J. D., ANDERSEN, H., LEWIS, M. G. \& BAROUCH, D. H. 2020. SARS-CoV-2 infection protects against rechallenge in rhesus macaques. Science, 369, 812-817.

CHEN, G., WU, D., GUO, W., CAO, Y., HUANG, D., WANG, H., WANG, T., ZHANG, X., CHEN, H., YU, H., ZHANG, X., ZHANG, M., WU, S., SONG, J., CHEN, T., HAN, M., LI, S., LUO, X., ZHAO, J. \& NING, Q. 2020. Clinical and immunological features of severe and moderate coronavirus disease 2019. J Clin Invest, 130, 2620-2629.

CHIPETA, J., KOMADA, Y., ZHANG, X. L., DEGUCHI, T., SUGIYAMA, K., AZUMA, E. \& SAKURAI, M. 1998. CD4+ and CD8+ cell cytokine profiles in neonates, older children, and adults: increasing $T$ helper type 1 and $T$ cytotoxic type 1 cell populations with age. Cell Immunol, 183, 149-56.

CRAWFORD, T. Q., HECHT, F. M., PILCHER, C. D., NDHLOVU, L. C. \& BARBOUR, J. D. 2013. Activation associated ERK1/2 signaling impairments in CD8+ T cells colocalize with blunted polyclonal and HIV-1 specific effector functions in early untreated HIV-1 infection. PLoS One, 8, e77412.

DENTON, A. E., RUSS, B. E., DOHERTY, P. C., RAO, S. \& TURNER, S. J. 2011. Differentiation-dependent functional and epigenetic landscapes for cytokine genes in virus-specific CD8+ T cells. Proc Natl Acad Sci U S A, 108, 15306-11.

DIAO, B., WANG, C., TAN, Y., CHEN, X., LIU, Y., NING, L., CHEN, L., LI, M., LIU, Y., WANG, G., YUAN, Z., FENG, Z., ZHANG, Y., WU, Y. \& CHEN, Y. 2020. Reduction and Functional Exhaustion of $T$ Cells in Patients With Coronavirus Disease 2019 (COVID-19). Front Immunol, 11, 827.

EDRIDGE, A. W. D., KACZOROWSKA, J., HOSTE, A. C. R., BAKKER, M., KLEIN, M., LOENS, K., JEBBINK, M. F., MATSER, A., KINSELLA, C. M., RUEDA, P., IEVEN, 
M., GoOssens, H., PRINS, M., SAStRe, P., DEIJS, M. \& VAN DER HOEK, L. 2020. Seasonal coronavirus protective immunity is short-lasting. Nat Med, 26, 16911693.

GARCIA-BELTRAN, W. F., LAM, E. C., ASTUDILLO, M. G., YANG, D., MILLER, T. E., FELDMAN, J., HAUSER, B. M., CARADONNA, T. M., CLAYTON, K. L., NITIDO, A. D., MURALI, M. R., ALTER, G., CHARLES, R. C., DIGHE, A., BRANDA, J. A., LENNERZ, J. K., LINGWOOD, D., SCHMIDT, A. G., IAFRATE, A. J. \& BALAZS, A. B. 2020. COVID-19-neutralizing antibodies predict disease severity and survival. Cell.

GREANEY, A. J., STARR, T. N., GILCHUK, P., ZOST, S. J., BINSHTEIN, E., LOES, A. N., HILTON, S. K., HUDDLESTON, J., EGUIA, R., CRAWFORD, K. H. D., DINGENS, A. S., NARGI, R. S., SUTTON, R. E., SURYADEVARA, N., ROTHLAUF, P. W., LIU, Z., WHELAN, S. P. J., CARNAHAN, R. H., CROWE, J. E., JR. \& BLOOM, J. D. 2020. Complete Mapping of Mutations to the SARS-CoV-2 Spike Receptor-Binding Domain that Escape Antibody Recognition. Cell Host Microbe.

GRIFONI, A., WEISKOPF, D., RAMIREZ, S. I., MATEUS, J., DAN, J. M., MODERBACHER, C. R., RAWLINGS, S. A., SUTHERLAND, A., PREMKUMAR, L., JADI, R. S., MARRAMA, D., DE SILVA, A. M., FRAZIER, A., CARLIN, A. F., GReEnbaum, J. A., PETERS, B., KRAMMER, F., SMITH, D. M., CROTTY, S. \& SETTE, A. 2020. Targets of T Cell Responses to SARS-CoV-2 Coronavirus in Humans with COVID-19 Disease and Unexposed Individuals. Cell, 181, 1489-1501 e15.

HACHIM, A., GU, H., KAVIAN, O., KWAN, M. Y. W., CHAN, W.-H., YAU, Y. S., CHIU, S. S., TSANG, O. T. Y., HUI, D. S. C., MA, F., LAU, E. H. Y., CHENG, S. M. S., POON, L. L. M., PEIRIS, J. S. M., VALKENBURG, S. A. \& KAVIAN, N. 2021. The SARSCoV-2 antibody landscape is lower in magnitude for structural proteins, diversified for accessory proteins and stable long-term in children. medRxiv, 2021.01.03.21249180.

HE, X. S., HOLMES, T. H., ZHANG, C., MAHMOOD, K., KEMBLE, G. W., LEWIS, D. B., DEKKER, C. L., GREENBERG, H. B. \& ARVIN, A. M. 2006. Cellular immune responses in children and adults receiving inactivated or live attenuated influenza vaccines. J Virol, 80, 11756-66.

ING, A. J., COCKS, C. \& GREEN, J. P. 2020. COVID-19: in the footsteps of Ernest Shackleton. Thorax, 75, 693-694. 
JONES, T. C., MÜHLEMANN, B., VEITH, T., BIELE, G., ZUCHOWSKI, M., HOFMANN, J., STEIN, A., EDELMANN, A., CORMAN, V. M. \& DROSTEN, C. 2020. An analysis of SARS-CoV-2 viral load by patient age. medRxiv, 2020.06.08.20125484.

JUNO, J. A., TAN, H. X., LEE, W. S., REYNALDI, A., KELLY, H. G., WRAGG, K., ESTERBAUER, R., KENT, H. E., BATTEN, J. C., MORDANT, F. L., GHERARDIN, N. A., PYMM, P., DIETRICH, M. H., SCOTT, N. E., THAM, W. H., GODFREY, D. I., SUBBARAO, K., DAVENPORT, M. P., KENT, S. J. \& K., W. A. 2020. Immunogenic profile of SARS-CoV-2 spike in individuals recovered from COVID-19. medRXiv.

KEMP, S. A., COLLIER, D. A., DATIR, R., FERREIRA, I., GAYED, S., JAHUN, A., HOSMILLO, M., REES-SPEAR, C., MLCOCHOVA, P., LUMB, I. U., ROBERTS, D. J., CHANDRA, A., TEMPERTON, N., SHARROCKS, K., BLANE, E., BRIGGS, J. A. G., VAN GILS, M. J., SMITH, K. G. C., BRADLEY, J. R., SMITH, C., DOFFINGER, R., CERON-GutieRreZ, L., BARCENAS-MORALES, G., POLLOCK, D. D., GOldSTEIN, R. A., SMIELEWSKA, A., SKITTRALL, J. P., GOULIOURIS, T., GOODFELLOW, I. G., GKRANIA-KLOTSAS, E., ILLINGWORTH, C. J. R., MCCOY, L. E. \& GUPTA, R. K. 2020. Neutralising antibodies in Spike mediated SARS-CoV-2 adaptation. medRxiv, 2020.12.05.20241927.

KINJYO, I., QIN, J., TAN, S. Y., WELLARD, C. J., MRASS, P., RITCHIE, W., DOI, A., CAVANAGH, L. L., TOMURA, M., SAKAUE-SAWANO, A., KANAGAWA, O., MIYAWAKI, A., HODGKIN, P. D. \& WENINGER, W. 2015. Real-time tracking of cell cycle progression during CD8+ effector and memory T-cell differentiation. Nat Commun, 6, 6301.

KRETSCHMER, L., FLOSSDORF, M., MIR, J., CHO, Y. L., PLAMBECK, M., TREISE, I., TOSKA, A., HEINZEL, S., SCHIEMANN, M., BUSCH, D. H. \& BUCHHOLZ, V. R. 2020. Differential expansion of $T$ central memory precursor and effector subsets is regulated by division speed. Nat Commun, 11, 113.

LAU, E. H. Y., TSANG, O. T. Y., HUI, D. S. C., KWAN, M. Y. W., CHAN, W. H., CHIU, S. S., KO, R. L. W., CHAN, K. H., CHENG, S. M. S., PERERA, R., COWLING, B. J., POON, L. L. M. \& PEIRIS, M. 2021. Neutralizing antibody titres in SARS-CoV-2 infections. Nat Commun, 12, 63.

LE BERT, N., TAN, A. T., KUNASEGARAN, K., THAM, C. Y. L., HAFEZI, M., CHIA, A., CHNG, M. H. Y., LIN, M., TAN, N., LINSTER, M., CHIA, W. N., CHEN, M. I., WANG, L. F., OOI, E. E., KALIMUDDIN, S., TAMBYAH, P. A., LOW, J. G., TAN, Y. J. \& BERTOLETTI, A. 2020. SARS-CoV-2-specific T cell immunity in cases of COVID-19 and SARS, and uninfected controls. Nature, 584, 457-462. 
LEWIS, D. B., YU, C. C., MEYER, J., ENGLISH, B. K., KAHN, S. J. \& WILSON, C. B. 1991. Cellular and molecular mechanisms for reduced interleukin 4 and interferon-gamma production by neonatal T cells. J Clin Invest, 87, 194-202.

LICHTERFELD, M., YU, X. G., WARING, M. T., MUI, S. K., JOHNSTON, M. N., COHEN, D., ADDO, M. M., ZAUNDERS, J., ALTER, G., PAE, E., STRICK, D., ALLEN, T. M., ROSENBERG, E. S., WALKER, B. D. \& ALTFELD, M. 2004. HIV-1-specific cytotoxicity is preferentially mediated by a subset of CD8+ $T$ cells producing both interferon- $y$ and tumor necrosis factor-a. Blood, 104, 487-494.

LONG, Q. X., TANG, X. J., SHI, Q. L., LI, Q., DENG, H. J., YUAN, J., HU, J. L., XU, W., ZHANG, Y., LV, F. J., SU, K., ZHANG, F., GONG, J., WU, B., LIU, X. M., LI, J. J., QIU, J. F., CHEN, J. \& HUANG, A. L. 2020. Clinical and immunological assessment of asymptomatic SARS-CoV-2 infections. Nat Med, 26, 1200-1204.

LUMLEY, S. F., O'DONNELL, D., STOESSER, N. E., MATTHEWS, P. C., HOWARTH, A., HATCH, S. B., MARSDEN, B. D., COX, S., JAMES, T., WARREN, F., PECK, L. J., RITTER, T. G., DE TOLEDO, Z., WARREN, L., AXTEN, D., CORNALL, R. J., JONES, E. Y., STUART, D. I., SCREATON, G., EBNER, D., HOOSDALLY, S., CHAND, M., CROOK, D. W., O'DONNELL, A. M., CONLON, C. P., POUWELS, K. B., WALKER, A. S., PETO, T. E. A., HOPKINS, S., WALKER, T. M., JEFFERY, K., EYRE, D. W. \& OXFORD UNIVERSITY HOSPITALS STAFF TESTING, G. 2020. Antibody Status and Incidence of SARS-CoV-2 Infection in Health Care Workers. $N$ Engl J Med.

MANN, E. R., MENON, M., KNIGHT, S. B., KONKEL, J. E., JAGGER, C., SHAW, T. N., KRISHNAN, S., RATTRAY, M., USTIANOWSKI, A., BAKERLY, N. D., DARK, P., LORD, G., SIMPSON, A., FELTON, T., HO, L. P., TRC, N. R., FELDMANN, M., CIRCO, GRAINGER, J. R. \& HUSSELL, T. 2020. Longitudinal immune profiling reveals key myeloid signatures associated with COVID-19. Sci Immunol, 5.

MATEUS, J., GRIFONI, A., TARKE, A., SIDNEY, J., RAMIREZ, S. I., DAN, J. M., BURGER, Z. C., RAWLINGS, S. A., SMITH, D. M., PHILLIPS, E., MALLAL, S., LAMMERS, M., RUBIRO, P., QUIAMBAO, L., SUTHERLAND, A., YU, E. D., DA SILVA ANTUNES, R., GREENBAUM, J., FRAZIER, A., MARKMANN, A. J., PREMKUMAR, L., DE SILVA, A., PETERS, B., CROTTY, S., SETTE, A. \& WEISKOPF, D. 2020. Selective and cross-reactive SARS-CoV-2 T cell epitopes in unexposed humans. Science, 370, 89-94.

MCMAHAN, K., YU, J., MERCADO, N. B., LOOS, C., TOSTANOSKI, L. H., CHANDRASHEKAR, A., LIU, J., PETER, L., ATYEO, C., ZHU, A., BONDZIE, E. A., DAGOTTO, G., GEBRE, M. S., JACOB-DOLAN, C., LI, Z., NAMPANYA, F., PATEL, 
S., PESSAINT, L., VAN RY, A., BLADE, K., YALLEY-OGUNRO, J., CABUS, M., BROWN, R., COOK, A., TEOW, E., ANDERSEN, H., LEWIS, M. G., LAUfFEnBuRGER, D. A., ALTER, G. \& BAROUCH, D. H. 2020. Correlates of protection against SARS-CoV-2 in rhesus macaques. Nature.

MOK, C. K. P., ZHU, A., ZHAO, J., LAU, E. H. Y., WANG, J., CHEN, Z., ZHUANG, Z., WANG, Y., ALSHUKAIRI, A. N., BAHAROON, S. A., WANG, W., TAN, W., LIANG, W., OLADIPO, J. O., PERERA, R., KURANGA, S. A., PEIRIS, M. \& ZHAO, J. 2020. T-cell responses to MERS coronavirus infection in people with occupational exposure to dromedary camels in Nigeria: an observational cohort study. Lancet Infect Dis.

PENG, Y., MENTZER, A. J., LIU, G., YAO, X., YIN, Z., DONG, D., DEJNIRATTISAI, W., ROSTRON, T., SUPASA, P., LIU, C., LOPEZ-CAMACHO, C., SLON-CAMPOS, J., ZHAO, Y., STUART, D. I., PAESEN, G. C., GRIMES, J. M., ANTSON, A. A., BAYFIELD, O. W., HAWKINS, D., KER, D. S., WANG, B., TURTLE, L., SUBRAMANIAM, K., THOMSON, P., ZHANG, P., DOLD, C., RATCLIFF, J., SIMMONDS, P., DE SILVA, T., SOPP, P., WELLINGTON, D., RAJAPAKSA, U., CHEN, Y. L., SALIO, M., NAPOLITANI, G., PAES, W., BORROW, P., KESSLER, B. M., FRY, J. W., SCHWABE, N. F., SEMPLE, M. G., BAILLIE, J. K., MOORE, S. C., OPENSHAW, P. J. M., ANSARI, M. A., DUNACHIE, S., BARNES, E., FRATER, J., KERR, G., GOULDER, P., LOCKETT, T., LEVIN, R., ZHANG, Y., JING, R., HO, L. P., OXFORD IMMUNOLOGY NETWORK COVID-19 RESPONSE, T. C. C., INVESTIGATORS, I. C., CORNALL, R. J., CONLON, C. P., KLENERMAN, P., SCREATON, G. R., MONGKOLSAPAYA, J., MCMICHAEL, A., KNIGHT, J. C., OGG, G. \& DONG, T. 2020. Broad and strong memory CD4(+) and CD8(+) T cells induced by SARS-CoV-2 in UK convalescent individuals following COVID-19. Nat Immunol, 21, 1336-1345.

PILKINTON, M. A., NICHOLAS, K. J., WARREN, C. M., SMITH, R. M., YODER, S. M., TALBOT, H. K. \& KALAMS, S. A. 2017. Greater activation of peripheral T follicular helper cells following high dose influenza vaccine in older adults forecasts seroconversion. Vaccine, 35, 329-336.

RODDA, L. B., NetLAND, J., ShehATA, L., PRUNER, K. B., MORAWSKI, P. A., THOUVENEL, C. D., TAKEHARA, K. K., EGGENBERGER, J., HEMANN, E. A., WATERMAN, H. R., FAHNING, M. L., CHEN, Y., HALE, M., RATHE, J., STOKES, C., WRENN, S., FIALA, B., CARTER, L., HAMERMAN, J. A., KING, N. P., GALE, M., JR., CAMPBELL, D. J., RAWLINGS, D. J. \& PEPPER, M. 2021. Functional 
SARS-CoV-2-Specific Immune Memory Persists after Mild COVID-19. Cell, 184, 169-183 e17.

RUDOLPH, M. E., MCARTHUR, M. A., BARNES, R. S., MAGDER, L. S., CHEN, W. H. \& SZTEIN, M. B. 2018. Differences Between Pediatric and Adult T Cell Responses to In Vitro Staphylococcal Enterotoxin B Stimulation. Front Immunol, 9, 498.

RYDYZNSKI MODERBACHER, C., RAMIREZ, S. I., DAN, J. M., GRIFONI, A., HASTIE, K. M., WEISKOPF, D., BELANGER, S., ABBOTT, R. K., KIM, C., CHOI, J., KATO, Y., CROTTY, E. G., KIM, C., RAWLINGS, S. A., MATEUS, J., TSE, L. P. V., FRAZIER, A., BARIC, R., PETERS, B., GREENBAUM, J., OLLMANN SAPHIRE, E., SMITH, D. M., SETTE, A. \& CROTTY, S. 2020. Antigen-Specific Adaptive Immunity to SARSCoV-2 in Acute COVID-19 and Associations with Age and Disease Severity. Cell, 183, 996-1012 e19.

SEKINE, T., PEREZ-POTTI, A., RIVERA-BALLESTEROS, O., STRALIN, K., GORIN, J. B., OLSSON, A., LLEWELLYN-LACEY, S., KAMAL, H., BOGDANOVIC, G., MUSCHIOL, S., WULLIMANN, D. J., KAMMANN, T., EMGARD, J., PARROT, T., FOLKESSON, E., KAROLINSKA, C.-S. G., ROOYACKERS, O., ERIKSSON, L. I., HENTER, J. I., SONNERBORG, A., ALLANDER, T., ALBERT, J., NIELSEN, M., KLINGSTROM, J., GREDMARK-RUSS, S., BJORKSTROM, N. K., SANDBERG, J. K., PRICE, D. A., LJUNGGREN, H. G., ALEMAN, S. \& BUGGERT, M. 2020. Robust T Cell Immunity in Convalescent Individuals with Asymptomatic or Mild COVID-19. Cell, 183, 158-168 e14.

SELVA, K. J., VAN DE SANDT, C. E., LEMKE, M. M., LEE, C. Y., SHOFFNER, S. K., CHUA, B. Y., NGUYEN, T. H. O., ROWNTREE, L. C., HENSEN, L., KOUTSAKOS, M., WONG, C. Y., JACKSON, D. C., FLANAGAN, K. L., CROWE, J., CHENG, A. C., DOOLAN, D. L., AMANAT, F., KRAMMER, F., CHAPPELL, K., MODHIRAN, N., WATTERSON, D., YOUNG, P., WINES, B., HOGARTH, P. M., ESTERBAUER, R., KELLY, H. G., TAN, H.-X., JUNO, J. A., WHEATLEY, A. K., KENT, S. J., ARNOLD, K. B., KEDZIERSKA, K. \& CHUNG, A. W. 2020. Distinct systems serology features in children, elderly and COVID patients. medRxiv, 2020.05.11.20098459.

SHANNON, I., WHITE, C. L., MURPHY, A., QIU, X., TREANOR, J. J. \& NAYAK, J. L. 2019. Differences in the influenza-specific CD4 T cell immunodominance hierarchy and functional potential between children and young adults. Sci Rep, 9, 791.

SRIDHAR, S., BEGOM, S., BERMINGHAM, A., HOSCHLER, K., ADAMSON, W., CARMAN, W., BEAN, T., BARCLAY, W., DEEKS, J. J. \& LALVANI, A. 2013. Cellular immune correlates of protection against symptomatic pandemic influenza. Nature Medicine, 19, 1305-1312. 
TAN, H.-X., LEE, W. S., WRAGG, K. M., NELSON, C., ESTERBAUER, R., KELLY, H. G., AMARASENA, T., JONES, R. M., STARKEY, G., WANG, B. Z., YOSHINO, O., TIANG, T., GRAYSON, M. L., OPDAM, H., COSTA, R., VAGO, A., MACKAY, L. K., GORDON, C. L., WHEATLEY, A. K., KENT, S. J. \& JUNO, J. A. 2021. Adaptive immunity to human coronaviruses is widespread but low in magnitude. medRxiv, 2021.01.24.21250074.

THEVARAJAN, I., NGUYEN, T. H. O., KOUTSAKOS, M., DRUCE, J., CALY, L., VAN DE SANDT, C. E., JIA, X., NICHOLSON, S., CATTON, M., COWIE, B., TONG, S. Y. C., LEWIN, S. R. \& KEDZIERSKA, K. 2020. Breadth of concomitant immune responses prior to patient recovery: a case report of non-severe COVID-19. Nat Med, 26, 453455.

TOSIF, S., NEELAND, M. R., SUTTON, P., LICCIARDI, P. V., SARKAR, S., SELVA, K. J., DO, L. A. H., DONATO, C., QUAN TOH, Z., HIGGINS, R., VAN DE SANDT, C., LEMKE, M. M., LEE, C. Y., SHOFFNER, S. K., FLANAGAN, K. L., ARNOLD, K. B., MORDANT, F. L., MULHOLLAND, K., BINES, J., DOHLE, K., PELLICCI, D. G., CURTIS, N., MCNAB, S., STEER, A., SAFFERY, R., SUBBARAO, K., CHUNG, A. W., KEDZIERSKA, K., BURGNER, D. P. \& CRAWFORD, N. W. 2020. Immune responses to SARS-CoV-2 in three children of parents with symptomatic COVID-19. Nat Commun, 11, 5703.

WANG, E. Y., MAO, T., KLEIN, J. , DAI, Y., HUCK, J. D., LIU, F., ZHENG, N. S., TING ZHOU, BENJAMIN ISRAELOW, PATRICK WONG, CAROLINA LUCAS, JULIO SILVA,, JI EUN OH, S. E., PEROTTI E. S., FISCHER, S. , CAMPBELL .,, FOURNIER, J. B., WYLLIE, A. L., CHANTAL B. F. VOGELS, OTT I. M., CHANEY C. KALINICH3, MARY E. PETRONE, A. E. W., CHARLES DELA CRUZ, SHELLI F., FARHADIAN, W. L. S., NATHAN D. GRUBAUGH, ALBERT I. KO, AKIKO IWASAKI, \& RING, A. M. 2020. Diverse Functional Autoantibodies in Patients with COVID-19. MedRXiv.

WEINREICH, D. M., SIVAPALASINGAM, S., NORTON, T., ALI, S., GAO, H., BHORE, R., MUSSER, B. J., SOO, Y., ROFAIL, D., IM, J., PERRY, C., PAN, C., HOSAIN, R., MAHMOOD, A., DAVIS, J. D., TURNER, K. C., HOOPER, A. T., HAMILTON, J. D., BAUM, A., KYRATSOUS, C. A., KIM, Y., COOK, A., KAMPMAN, W., KOHLI, A., SACHDEVA, Y., GRABER, X., KOWAL, B., DICIOCCIO, T., STAHL, N., LIPSICH, L., BRAUNSTEIN, N., HERMAN, G., YANCOPOULOS, G. D. \& TRIAL, I. 2020. REGN-COV2, a Neutralizing Antibody Cocktail, in Outpatients with Covid-19. N Engl $J$ Med. 
WEISBERG, S. P., CONNORS, T. J., ZHU, Y., BALDWIN, M. R., LIN, W. H., WONTAKAL, S., SZABO, P. A., WELLS, S. B., DOGRA, P., GRAY, J., IDZIKOWSKI, E., STELITANO, D., BOVIER, F. T., DAVIS-PORADA, J., MATSUMOTO, R., POON, M. M. L., ChAit, M., MATHIEU, C., HORVAT, B., DECIMO, D., HUDSON, K. E., ZOTTI, F. D., BITAN, Z. C., LA CARPIA, F., FERRARA, S. A., MACE, E., MILNER, J., MOsconA, A., HOD, E., POROTTO, M. \& FARBER, D. L. 2021. Distinct antibody responses to SARS-CoV-2 in children and adults across the COVID-19 clinical spectrum. Nat Immunol, 22, 25-31.

WENINGER, W., CROWLEY, M. A., MANJUNATH, N. \& VON ANDRIAN, U. H. 2001. Migratory properties of naive, effector, and memory CD8(+) T cells. J Exp Med, 194, 953-66.

ZHANG, D., GUO, R., LEI, L., LIU, H., WANG, Y., WANG, Y., QIAN, H., DAI, T., ZHANG, T., LAI, Y., WANG, J., LIU, Z., CHEN, T., HE, A., O'DWYER, M. \& HU, J. 2021. Frontline Science: COVID-19 infection induces readily detectable morphologic and inflammation-related phenotypic changes in peripheral blood monocytes. Journal of Leukocyte Biology, 109, 13-22.

ZHAO, J., ALSHUKAIRI, A. N., BAHAROON, S. A., AHMED, W. A., BOKHARI, A. A., NEHDI, A. M., LAYQAH, L. A., ALGHAMDI, M. G., AL GETHAMY, M. M., DADA, A. M., KHALID, I., BOUJELAL, M., AL JOHANI, S. M., VOGEL, L., SUBBARAO, K., MANGALAM, A., WU, C., TEN EYCK, P., PERLMAN, S. \& ZHAO, J. 2017. Recovery from the Middle East respiratory syndrome is associated with antibody and T-cell responses. Sci Immunol, 2. 
A

Acute/admission

range: 1-14 days post infection
Convalescent

range: $15-60$ days
Long term memory

range: $61-180$ days

B

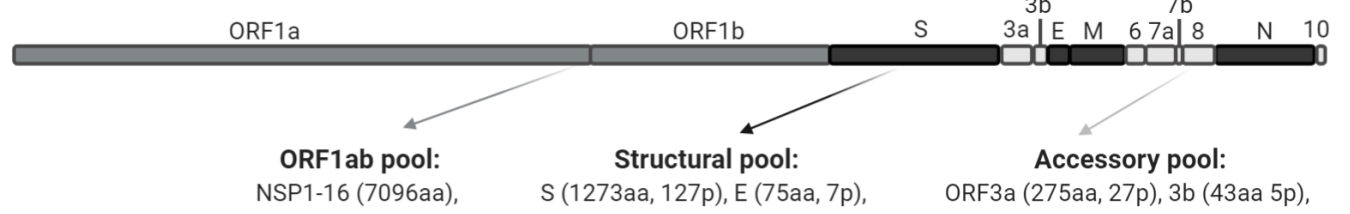

SP1-16 (7096aa) _ S (1273aa, 127p), E (75aa, 7p) ORF3a (275aa, 27p), 3b (43aa 5p),

709 peptides $\quad M(222 a a, 22 p), N(419 a a, 41 p), 6(61 a a, 6 p), 7 a(121 a a, 12 p), 7 b(43 a a, 3 p)$, 197 peptides $8(121 a a, 12 p), 10(43 a a, 3 p)$,

C

Structural

令

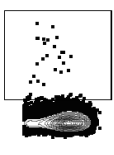

$\mathrm{CD} 8 \rightarrow$

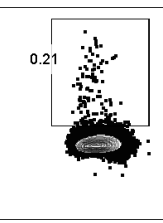

Accessory

$\mathrm{CD} 4 \rightarrow$
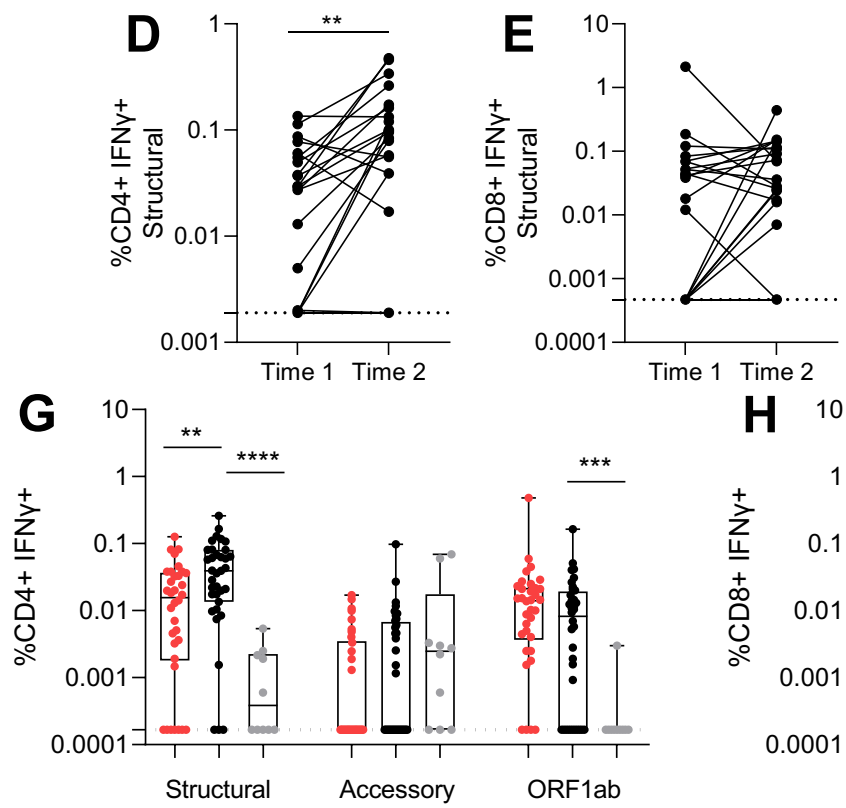

ORF1ab
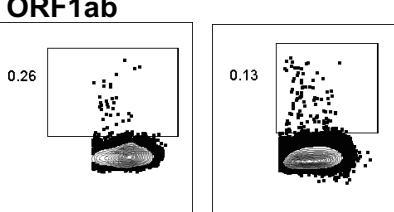

69 peptide
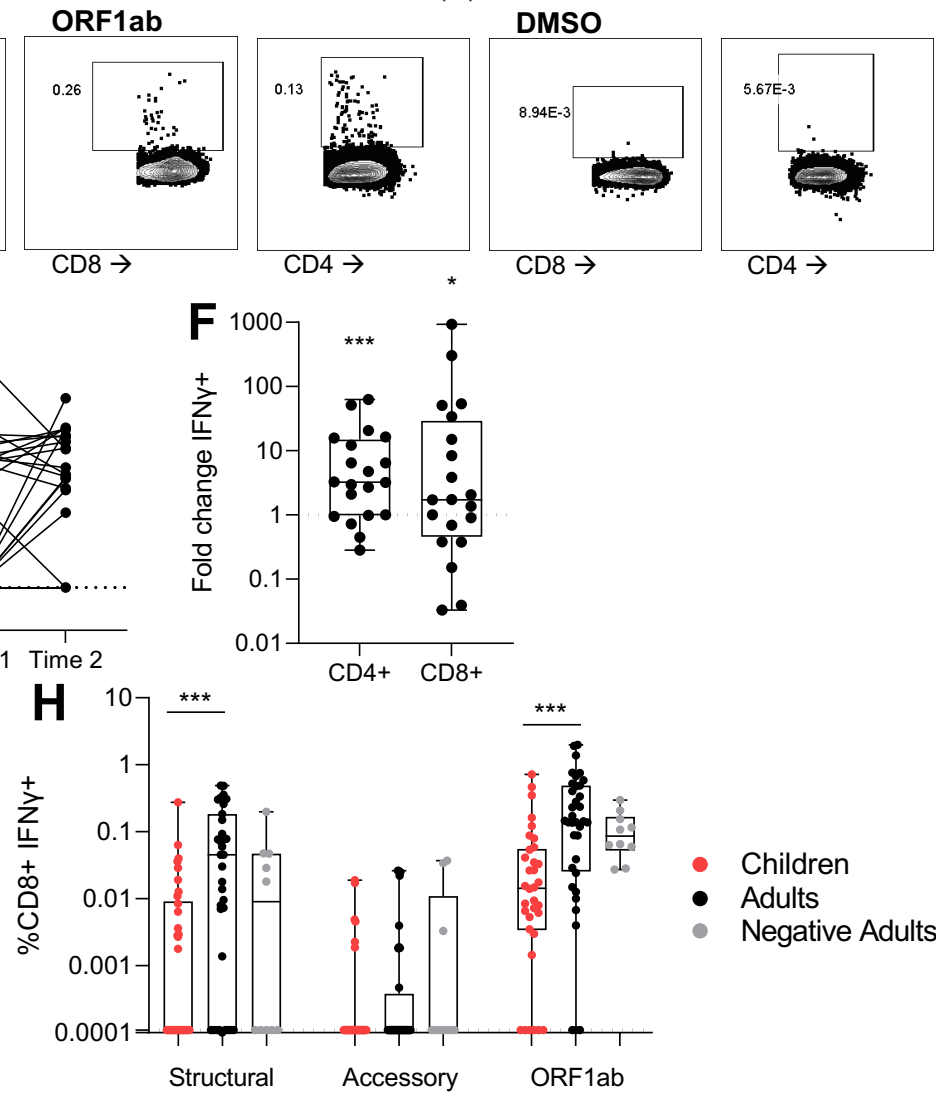

\begin{tabular}{|c|c|c|c|c|c|c|}
\hline \multirow{2}{*}{$\begin{array}{c}\%+ \\
\text { responders }\end{array}$} & \multicolumn{2}{|c|}{ Children $(n=34)$} & \multicolumn{2}{|c|}{ Adults $(n=36)$} & \multicolumn{2}{|c|}{ Negative Adults $(n=10)$} \\
\hline & CD4 & CD8 & CD4 & CD8 & CD4 & CD8 \\
\hline Structural & $79.4(27)$ & $44.1(15)$ & $94.3(33)$ & $74.3(26)^{*}$ & $50(5)$ & $50(5)$ \\
\hline Accessory & $32.4(11)$ & $17.6(6)$ & $47.2(17)$ & $25(9)$ & $70(7)$ & $30(3)$ \\
\hline ORF1ab & $88.2(30)$ & $82.4(28)$ & $69.4(25)$ & $91.7(33)$ & $10(1)$ & $100(10)$ \\
\hline
\end{tabular}

Children

J

CD4+ IFNy

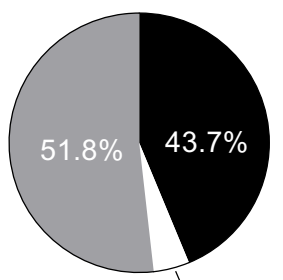

$4.5 \%$
Adults

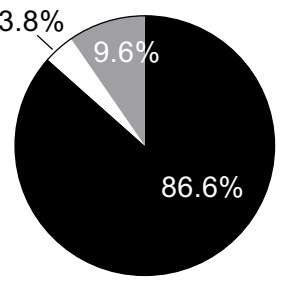

Negative Adults

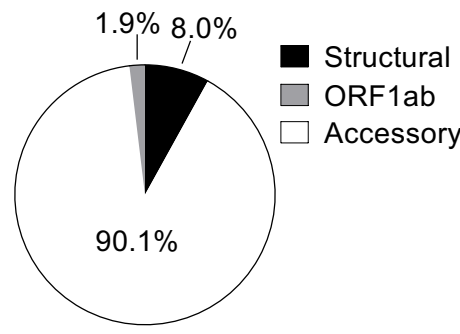

$\%$ CD4+IFNy (mean \pm stdev)

$0.042 \pm 0.13$

$0.049 \pm 0.12$

$0.013 \pm 0.02$

K

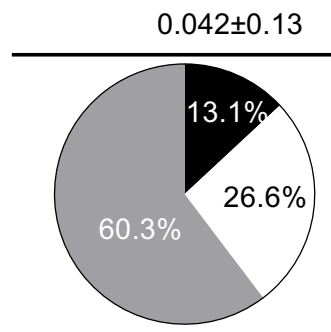

$\mathrm{CD}^{+} \mathrm{IFNY}$

$0.079 \pm 0.19$

$0.248 \pm 0.39$

$0.086 \pm 0.080$ 
A

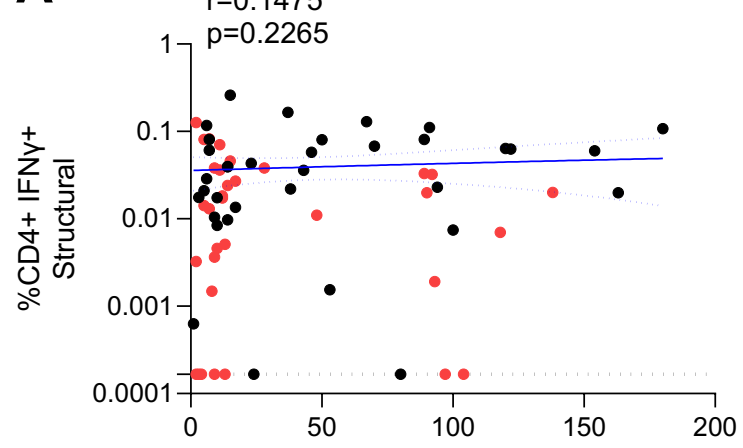

C Structural

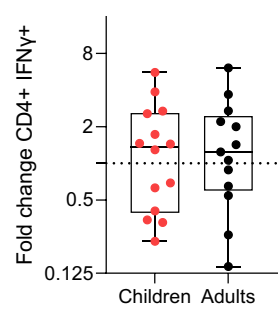

E

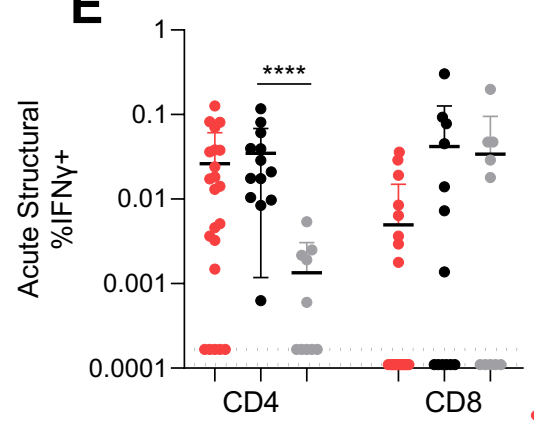

H
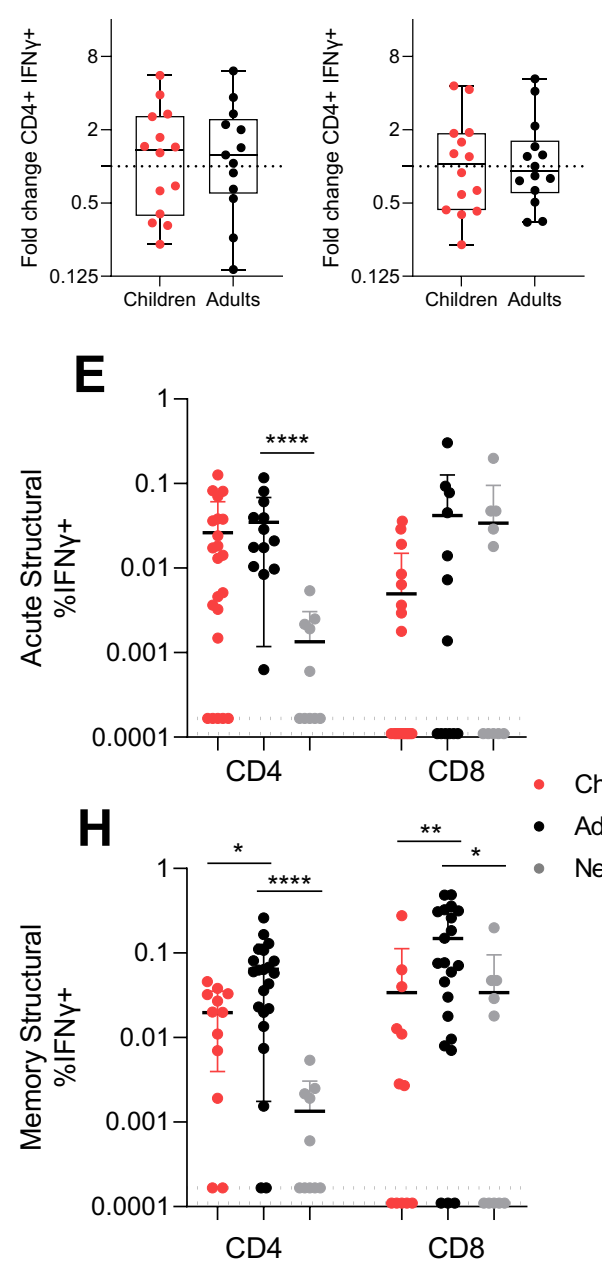

F
B

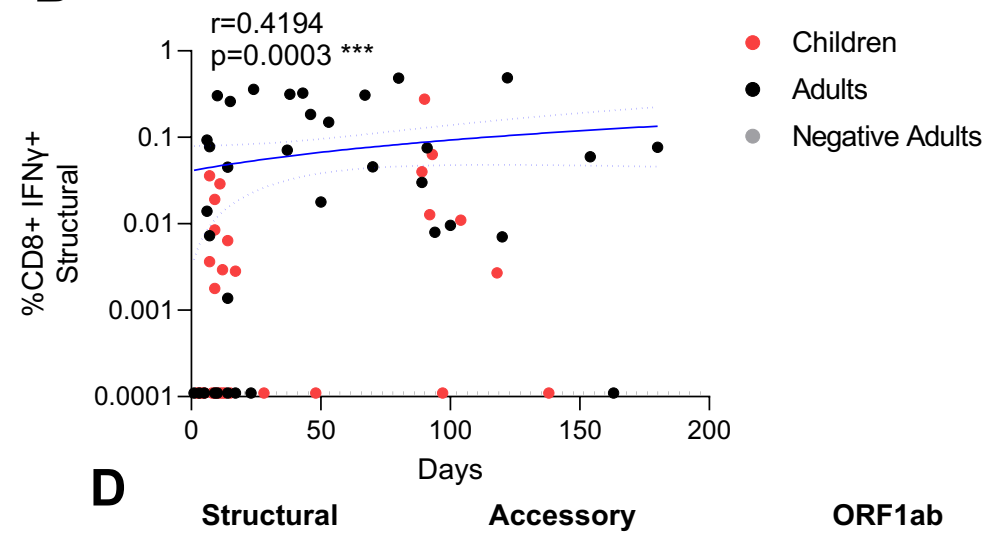

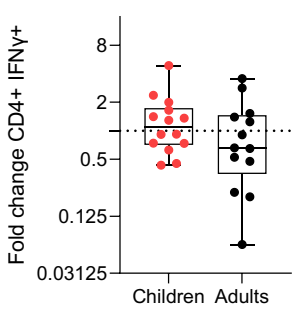
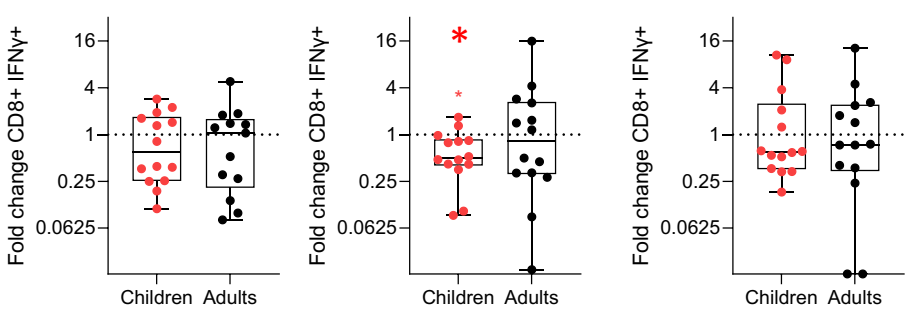

G

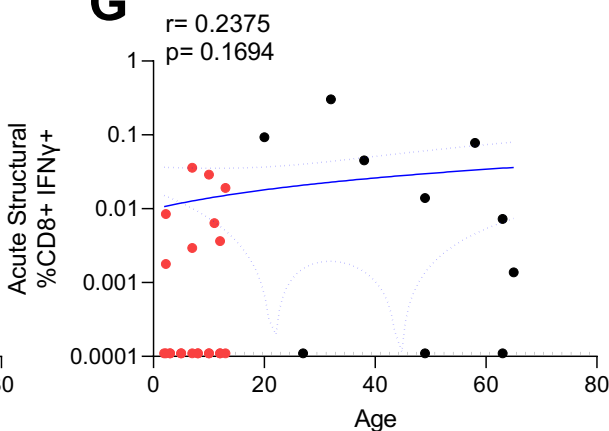

J
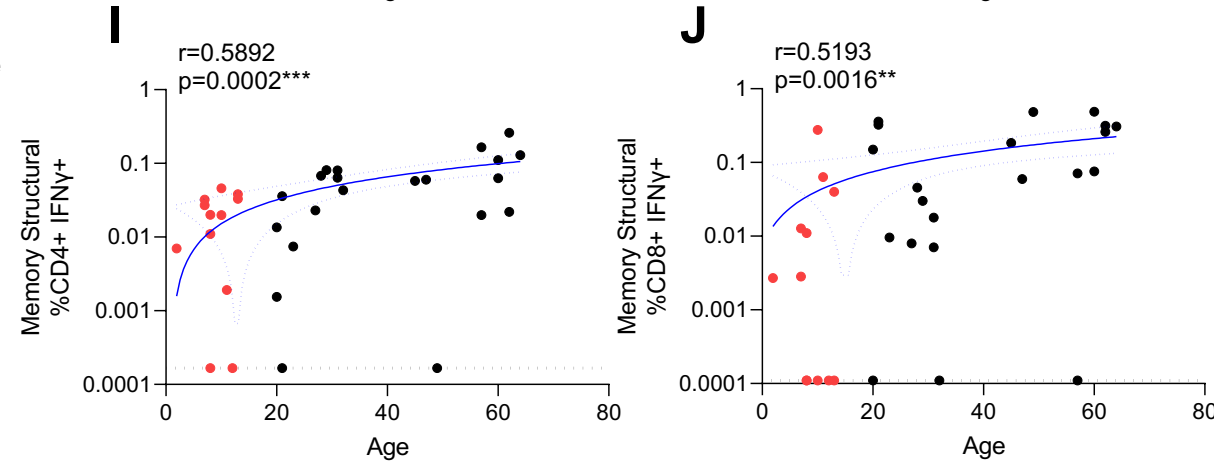

Figure 2 


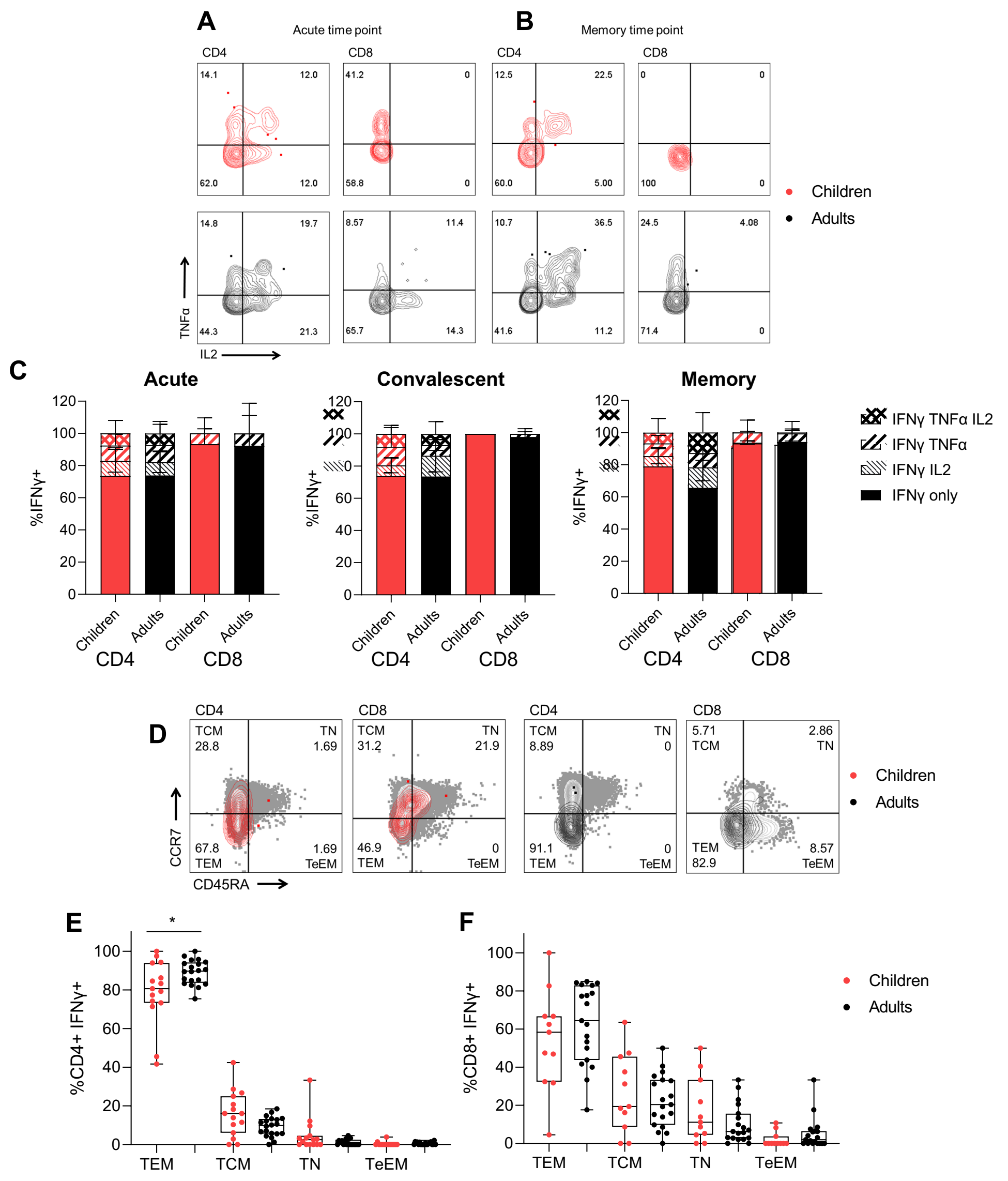

Figure 3 
A $\alpha$-Corona virus Spike

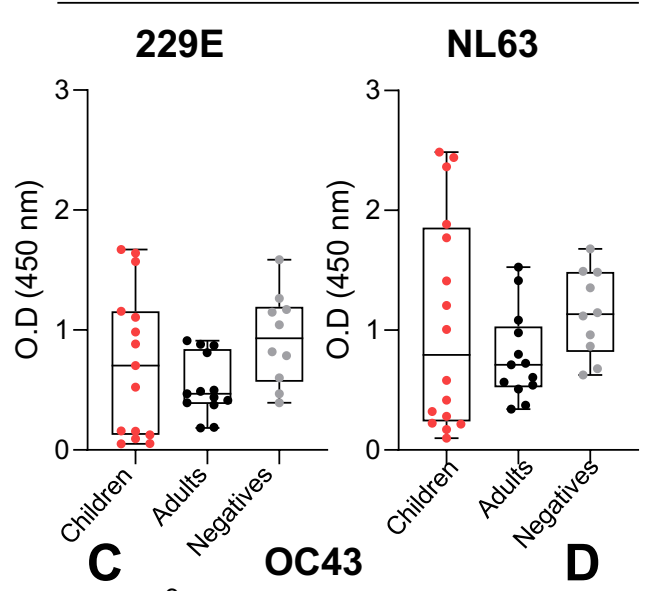

D

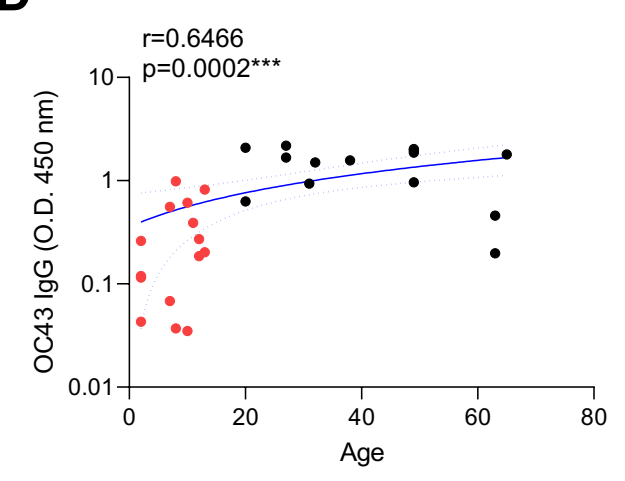

E

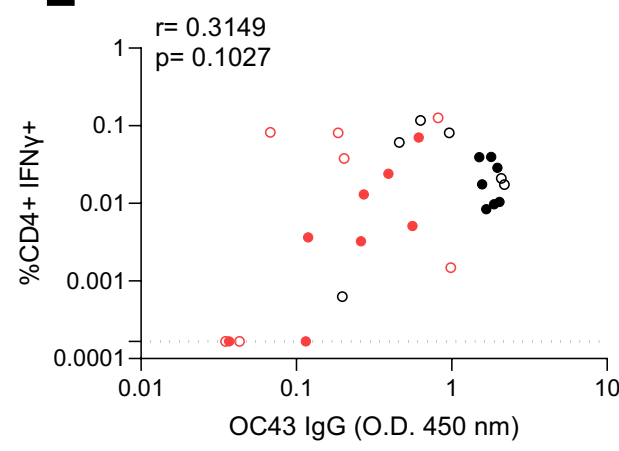

B $\quad \beta$-Corona virus Spike

HKU1 OC43
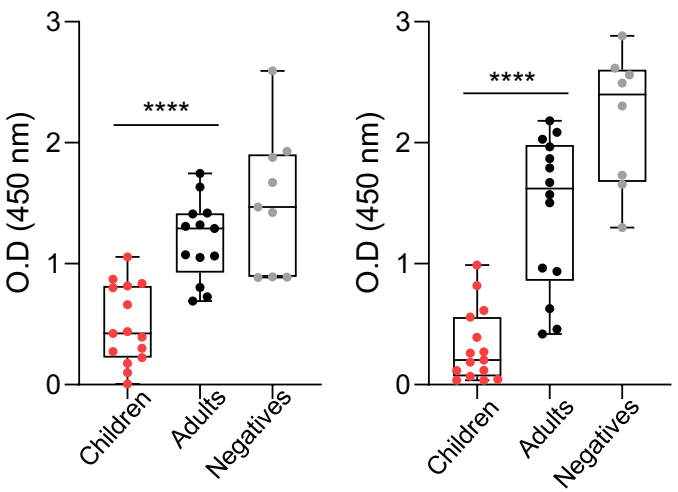

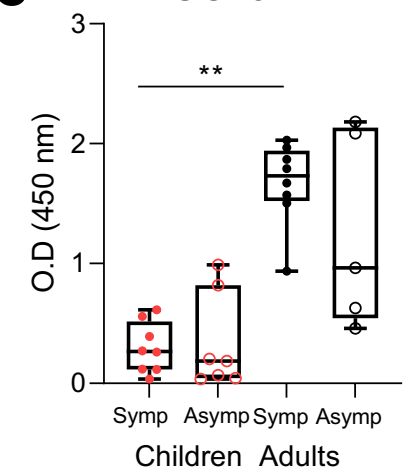

F

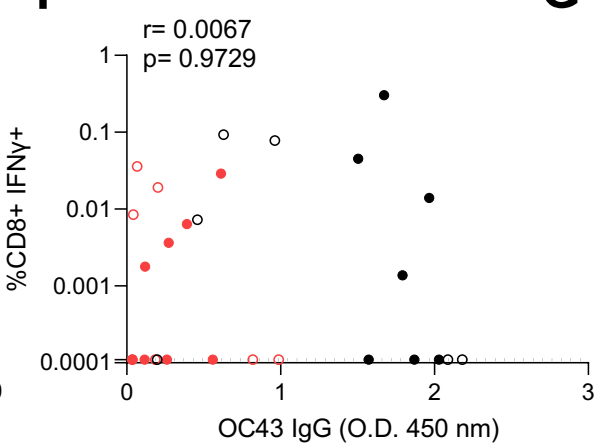

G

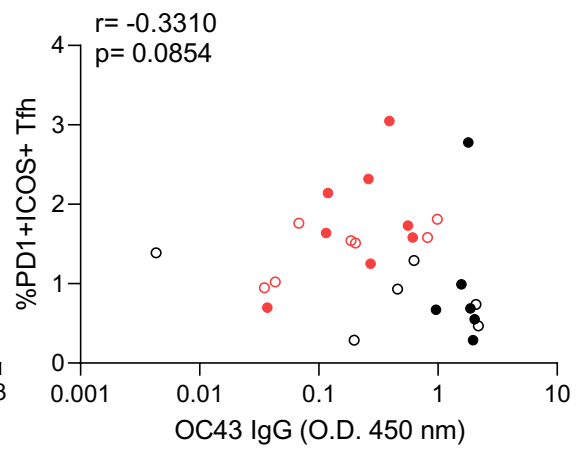


Table 1 - Summary of cohort information. Samples from SARS-CoV-2 infected children and adults, and negative controls forming a cohort where samples were used in multiple cellular and ELISA assays.

\begin{tabular}{|c|c|c|c|c|}
\hline n (\%) & Children & Adults & P value & Negatives \\
\hline Total donors & 24 & 45 & & 10 \\
\hline $\begin{array}{l}\text { Age (mean } \pm \\
\text { stdev, range) }\end{array}$ & $\begin{array}{l}7.8 \pm 3.9 \\
1.92-13 \text { years }\end{array}$ & $\begin{array}{l}43 \pm 4.0 \\
20-65 \text { years }\end{array}$ & $<0.0001$ & $\begin{array}{l}37.6 \pm 13.0 \\
19-57 \text { years }\end{array}$ \\
\hline Female (\%) & $54 \%(13)$ & $52 \%(23)$ & $>0.9999$ & $40 \%(4)$ \\
\hline \multicolumn{5}{|c|}{ Symptom Severity } \\
\hline Asymptomatic & $38 \%(9)$ & $20 \%(9)$ & & $\mathrm{N} / \mathrm{A}$ \\
\hline Mild/ Moderate & $62 \%(15)$ & $80 \%(36)$ & 0.1523 & $\mathrm{~N} / \mathrm{A}$ \\
\hline Severe/ Critical & $0 \%$ & $0 \%$ & & $\mathrm{~N} / \mathrm{A}$ \\
\hline \multicolumn{5}{|c|}{$\begin{array}{l}\text { Sample time point information }- \text { days post symptom onset }(n=\text {, mean } \pm \text { stdev, } \\
\text { range) }\end{array}$} \\
\hline All time points & $\begin{array}{l}n=44 \\
36 \pm 38 \\
2-138 \text { days }\end{array}$ & $\begin{array}{l}\mathrm{n}=75 \\
29 \pm 40 \\
1-180 \text { days }\end{array}$ & 0.262 & $\mathrm{~N} / \mathrm{A}$ \\
\hline $\begin{array}{l}\text { Acute time } \\
\text { points }\end{array}$ & $\begin{array}{l}\mathrm{n}=22 \\
8 \pm 3.8,2-14 \\
\text { days }\end{array}$ & $\begin{array}{l}\mathrm{n}=44 \\
8 \pm 4.0,1-14 \text { days }\end{array}$ & 0.949 & $\mathrm{~N} / \mathrm{A}$ \\
\hline $\begin{array}{l}\text { Convalescent } \\
\text { time points }\end{array}$ & $\begin{array}{l}\mathrm{n}=12 \\
35 \pm 10.9,15-48 \\
\text { days }\end{array}$ & $\begin{array}{l}\mathrm{n}=19 \\
26 \pm 12.7,15-53 \\
\text { days }\end{array}$ & 0.074 & $\mathrm{~N} / \mathrm{A}$ \\
\hline $\begin{array}{l}\text { Long term } \\
\text { memory time } \\
\text { points }(d>60)\end{array}$ & $\begin{array}{l}\mathrm{n}=8 \\
103 \pm 38.7,89- \\
138 \text { days }\end{array}$ & $\begin{array}{l}\mathrm{n}=12 \\
111 \pm 35.8,67-180 \\
\text { days }\end{array}$ & 0.926 & $\mathrm{~N} / \mathrm{A}$ \\
\hline
\end{tabular}

NB: $P$ values are calculated to compare adults and children using Fisher's exact test to compare sex and symptom severity, and using Mann-Whitney to compare sample timepoint information. 